\title{
Performance evaluation of plastic spacers: proposal and development of evaluation methods
}

\section{Avaliação de desempenho de espaçadores plásticos: proposição e avanço de métodos de avaliação}
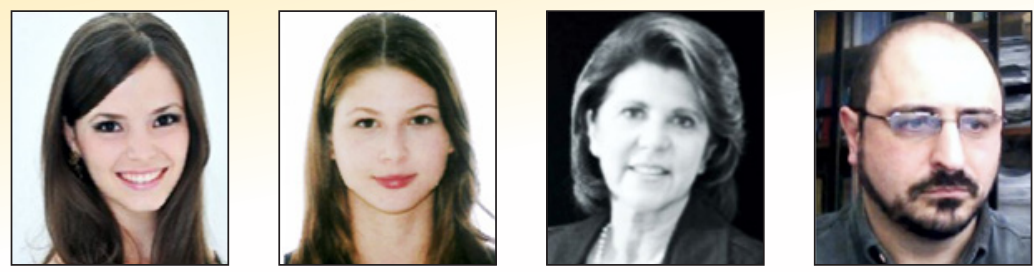

\author{
M. F. F. MENNA BARRETO \\ mfmennabarreto@gmail.com \\ A. P. MARAN b
} anapaulamaran@gmail.com

D. C. C. DAL MOLIN dmolin@ufrgs.br

J. R. MASUERO d

joao.masuero@ufrgs.br

\begin{abstract}
The durability of reinforced concrete structures is highly dependent on the characteristics of the concrete cover to reinforcement and its thickness. The failure to obtain cover thickness is the factor with the largest influence on the premature corrosion of the reinforcement, which in turn is the main deterioration form of reinforced concrete structures. Studies indicate that the designed cover is not reached in the current constructions that adopt this structural solution, configuring a chronic, and not a sporadic problem. One of the observed causes for the failure in obtaining the minimum standardized cover is the incorrect use of spacers and the use of inadequate spacers. This is made more serious by the absence of a Brazilian standard to regulate the product and its use and, consequently, the absence of a quality certification from the responsible regulating agency. Focusing on spacers, requirements and performance criteria were proposed, in addition to methods for their assessment, with most being taken and adapted from international standards. Subsequently, some spacers available on the market were effectively tested according to the proposed methodology. No spacer model proved to be satisfactory according to the established performance approach. However, for each criteria and assessment methods proposed, there was, at least, one spacer model at the market which satisfied them, so it can be said that the criteria and methods are suitable for spacers performance evaluation. Faced with the performance diversity of the spacer models on offer, the need for a regulatory Brazilian standard for this product was confirmed in order to delimit the quality of spacers available on the market and to eliminate this variable as one of the causes for not obtaining the correct covering
\end{abstract}

Keywords: concrete cover, cover to reinforcement, spacers, performance, reinforced concrete.

\section{Resumo}

A durabilidade de estruturas de concreto armado é altamente dependente das características do concreto de cobrimento das armaduras e sua espessura. $\mathrm{O}$ fracasso na obtenção do cobrimento é o fator de maior influência na corrosão prematura de armaduras que, por sua vez, é a principal forma de deterioração de estruturas de concreto armado. Pesquisas indicam que o cobrimento projetado não tem sido alcançado nas atuais obras que adotam esta solução estrutural, tratando-se de um problema crônico e não esporádico. Uma das causas observadas para falha na obtenção do cobrimento mínimo normalizado é o uso incorreto de espaçadores e a utilização de espaçadores inadequados. Isso se agrava pela falta de uma norma brasileira que regulamente o produto e seu uso e, consequentemente, a falta de certificação de qualidade pelo órgão responsável. Tendo como foco os espaçadores, foram propostos requisitos e critérios de desempenho, assim como métodos para avaliação dos mesmos, sendo a maioria compilada e adaptada de normas internacionais. Em seguida, alguns espaçadores disponíveis no mercado foram efetivamente testados segundo a metodologia proposta. Nenhum modelo de espaçador provou-se satisfatório segundo a abordagem de desempenho estabelecida. Entretanto, para cada um dos critérios e métodos de avaliação propostos houve pelo menos um modelo de espaçador do mercado que os satisfez, de modo que se pode afirmar que os critérios e métodos são adequados para avaliação de desempenho de espaçadores. Diante da diversidade de modelos e de desempenho dos espaçadores ofertados, ficou comprovada a necessidade de uma norma brasileira regulamentadora para este produto, a fim de balizar a qualidade dos espaçadores disponíveis no mercado e eliminar esta variável das causas da não obtenção do correto cobrimento

Palavras-chave: cobrimento, espaçadores, desempenho, concreto armado.

Universidade Federal do Rio Grande do Sul, Department of Civil Engineering, Engineering School, Building Innovation Center, Porto Alegre, Brasil. 


\section{Introduction}

The durability problems of concrete structures originate from the environmental actions of aggressive agents on concrete, and may cause the untimely deterioration, impair the structural performance and, in extreme cases, induce structural failure of the structure [1] The structural durability has both technical and economic significance [1], since when reinforced concrete structures deteriorate just after a few years in service, this can be considered a loss, with increasing frequency reports events of this nature since the 1970s [2]

The failure to achieve the concrete cover to reinforcement is probably the greatest single factor influencing the premature reinforcement corrosion [3], which in turn is the main pathway for the deterioration of reinforced concrete structures [4]. However, the failure in obtaining the proper concrete cover is usually not seen as a problem by engineers, which is why it's not given priority [4].

One of the biggest problems related to these structures, therefore, is the inability to position the reinforcement with the correct concrete cover, which directly affects the mechanical behavior and the durability of the structure [5], requiring corrective actions involving costly repairs [6].

Many studies around the world, however, have shown that the cover reached during concreting usually does not meet the design expectations [3], i.e. the minimum designed cover is not completely reached in the current construction that adopt this structural solution [4][7][8].

The assured provision of an adequate thickness of concrete of appropriate quality, properly compacted and cured, would result in a considerable reduction of resources amount spent annually in the world for the premature replacement and repair of concrete structures [3].

Many of the problems that result in insufficient covering are related with defects in the project, design or supplied materials, and probably can only be resolved by addressing them at their source of origin [3].

Regarding the construction process, the cover issue is directly related to the spacers, because they are responsible for the correct positioning of the reinforcement and should provide for its adequate protection [9].

Spacers are essential for reinforced and prestressed concrete structures, and their use is recommended by ABNT NBR 14931 [10]. They are widely used in large quantities in constructions that adopt this structural solution, which includes most construction projects in the country.

The inadequate production and use of spacers, however, is one of the main causes of the wrong positioning of reinforcements [11]. The lack of a Brazilian standard that regulates the production and use of spacers and, consequently, the absence of a quality certification from a regulating agency of these products, contribute to the worsening of this situation.

This situation extends to other countries, such as Spain. Although this last country adopts recommendations for spacers according to the CEB Bulletins \#201 [12], there is no standardizing body that enables an assessment of the different distinct existing spacers on the Spanish market, which could provide for an appropriate performance standard for the projects [9].

In contrast, the United Kingdom doesn't only have a standard that defines the performance requirements and the evaluation methods for spacers - British Standard BS 7973 [11] - there is also a certification agency (CARES - Certification Authority Reinforcing Steels) responsible for providing confidence to users, buyers and specifiers of structural steels through a regulatory regime, tests and inspections.

Although this does not exist in Brazil yet, it is important to look for products that have been tested in laboratories and certified voluntarily by the manufacturer [13]. In some cases, however, the data provided by the manufacturer doesn't represent the relevant characteristics or properties, mainly with regard to the strength and the durability of the material or system [14].

After all, that is evident the necessary of a Brazilian standard for spacers so as to regulate their production and use, and, consequently, to supervise and certify the quality of existing spacers on the national market through a regulating agency, eliminating those products with poor performance and thus encouraging the search for excellence in the products supplied by the industries.

In this sense, a performance approach was chosen for the evaluation of plastic spacers, defining requirements, criteria and methods for their evaluation. Subsequently, some spacer models available on the national market were evaluated in order to verify their performance in ensuring the specified cover and, consequently, the durability of the structures.

\section{Performance requirements and criteria}

The performance concept can be applied to different decomposition and aggregation levels of a construction project: the construction as a whole, its elements, components and materials [15]

Establishing performance is a common and internationally practice that uses the definition of requirements (qualitative), criteria (quantitative) and assessment methods to enable its clear measurement [16].

According to ABNT NBR 15575 [16], performance requirements are conditions that qualitatively express the attributes that the product must possess in order to meet the requirements of the users. In turn, performance criteria are quantitative specifications of performance requirements, expressed in terms of measurable quantities, so that they can be objectively determined.

With this in mind, a Brazilian standard based on the performance of all and any item of construction is desirable. However, there is still a gap in this regard concerning to spacers, and the absence of a Brazilian standard regulating them prevents the control and supervision of this material, enabling the emergence of inadequate products on the market.

By the absence of a Brazilian standard, it was proposed performance requirements and criteria, sometimes based on international standard, other times completing them with new requirements and criteria.

\subsection{Dimensional}

The dimensional requirements and criteria are established based on European standard CEB Bulletins \#201 [12] and British Standard BS 7973-1 [11], and consist of:

a) providing a single covering value [12] or at most two covering values for the same spacer, provided that these have to be 
Figure 1 - Example of a spacer with two possible application positions: a) straight (b) upside down (9)

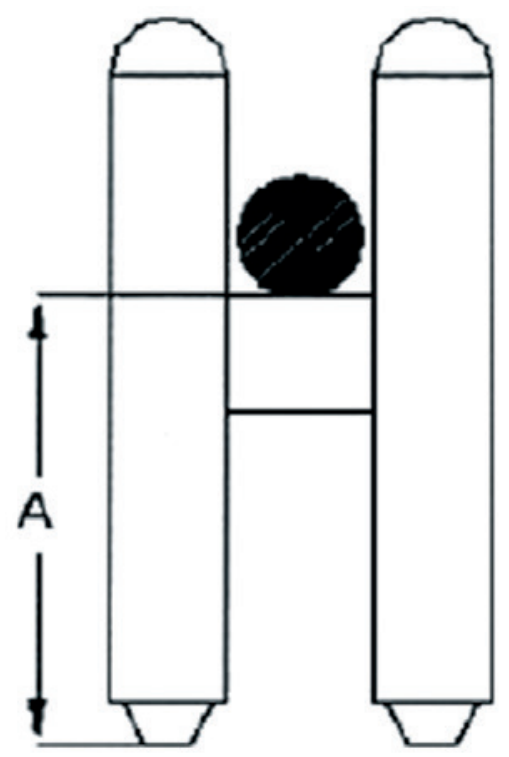

A

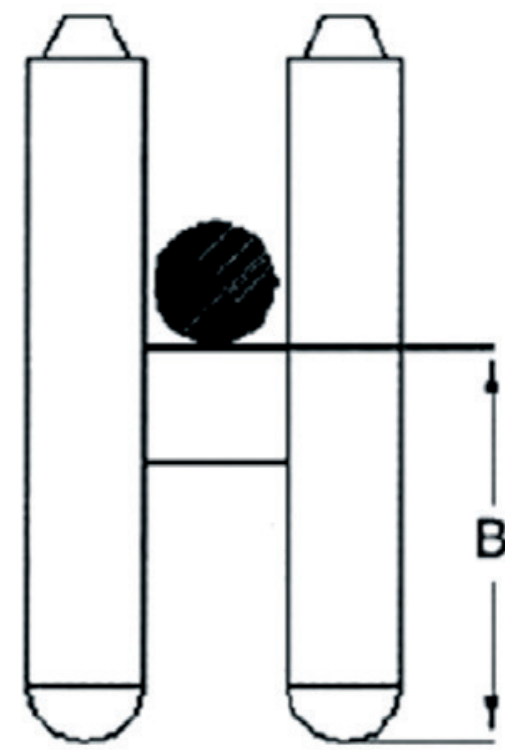

B clearly identified in the product [11]. This will avoid errors in its application, where the reversal of its placement generates undetectable differences in its covering, as illustrated in Figure 1;

b) ensuring the nominal covering. To this end, the spacer cover must be precisely provide by the manufacturer at the time of its use, with a tolerance of $\pm 1 \mathrm{~mm}$ for coverings up to $75 \mathrm{~mm}$ and $\pm 2 \mathrm{~mm}$ for larger coverings [11][12]. The spacer must possess this dimension from the support base until the final positioning of the steel in the product; c) minimum dimensions [11][12]: for models that are fixed with the aid of wires (chairs and multi-support spacers), their base must be at least $20 \mathrm{~mm}$ and at most $350 \mathrm{~mm}$ measured in the direction parallel to the steel bar, and at least 0.75 of the size of the covering measured perpendicular to the bar, according to the guidelines of Figure 2a. For circular models, the center of the support where the bar is mounted (Figure $2 \mathrm{~b}$ ) has to provide a thickness greater than 0.5 of the provided covering.

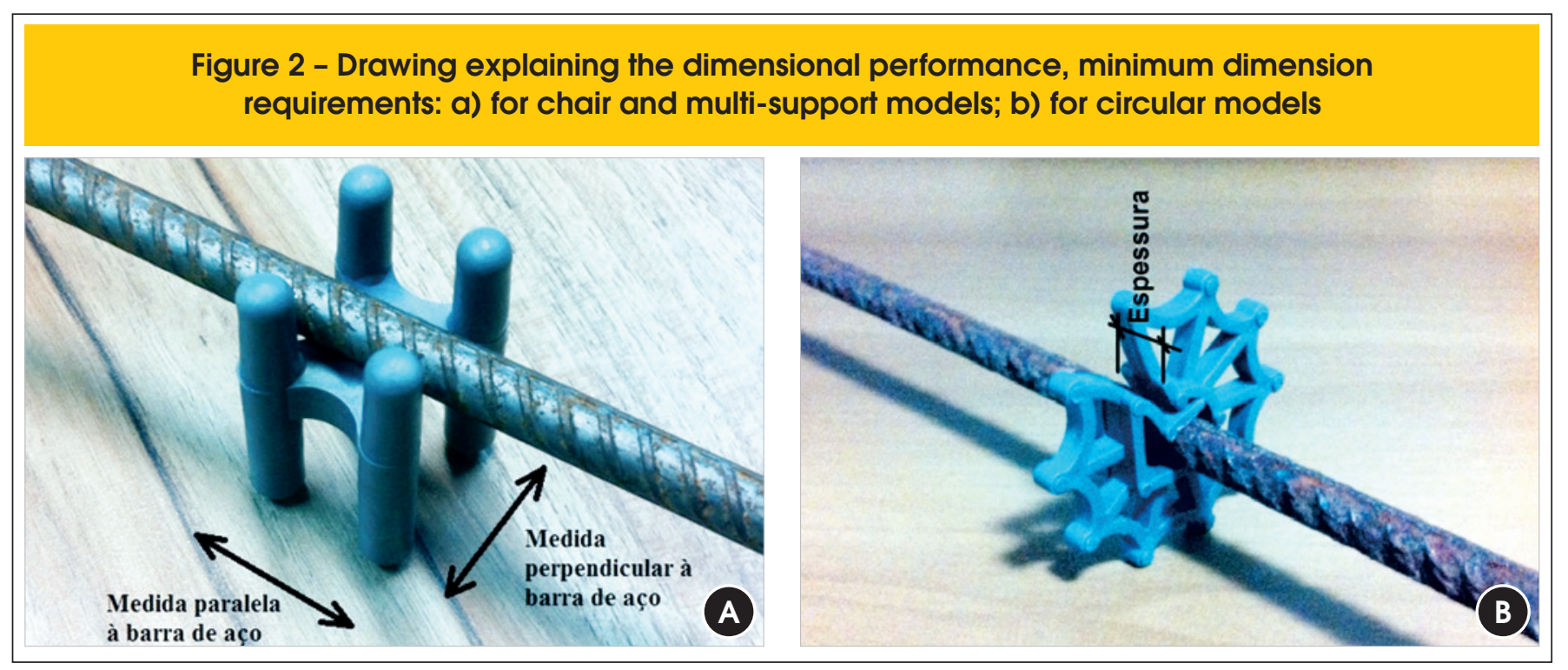


Figure 3 - Explanation of the identification requirement: a) size of the covering on the product; (b) separate colors between spacers with different coverings; c) spacer from the same manufacturer, of the same type and the same model, but with different coverings

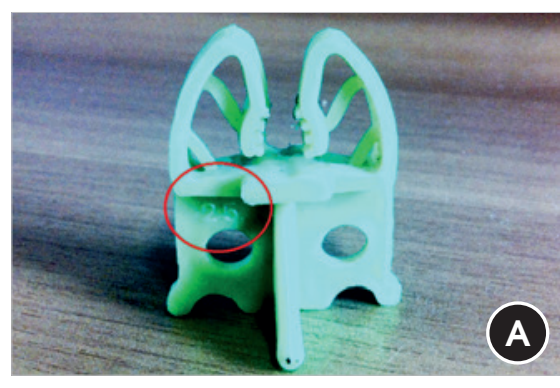

\subsection{Identification}

The product should be easy to identify, even when mixed. That is, the size of the nominal covering must be visibly indicated on the product itself [11], as shown in Figure 3a.

Although no standard requires the spacer to be identified, beyond the identification of the product's covering, when the same model is concerned, but with different covering values, these must have distinct colors as indicated in Figure $3 \mathrm{~b}$. This way, prevents that one specified spacer is confused with another during concreting operations with different thicknesses of covering, a situation similar to Figure 3c.

\subsection{Fixity}

The spacer must have the capacity to fixity the reinforcement bars and resist the displacement of a steel bar with a load of $5 \mathrm{~N}$ [11] [12]. As such, every spacer must possess an integrated fixity element so that it will attach to the reinforcements, without dropping or losing its function, as illustrated in Figure 4. The fixity item (as wire use) should not be the responsibility of the team responsible for the assembly of the reinforcements at the concreting, because this would cause the risk of it not being executed. That is why an integrated fixity is necessary.

\subsection{Stability}

The spacer must have a minimum stability, so that when be required during a concreting operation, it continues doing its part, avoiding problems like tipping, shown in Figure 5.

\subsection{Load capacity}

The spacer must remain intact during the concreting process, resisting the load to which it is exposed - such as the weight of the reinforcements, the assembly and concreting operations, the weight of workers and machines, among others - with a minimum estimated load of 3,0 kN (maximum strength suggested by CEB Bulletins \#201 [12] and by the British Standard BS 7973-1 [11]) for spacers facing great demands, such as those used in concrete slabs and beam bottom (chair-type and multiple support spacers), and a minimum load of $0.25 \mathrm{kN}$ (light strength suggested by the CEB Bulletins\# 201 [12] and by the British Standard BS 7973-1 [11]) for spacers used on the sides

\section{Figure 4 - Spacers that came loose from the reinforcement, no longer performing its function}
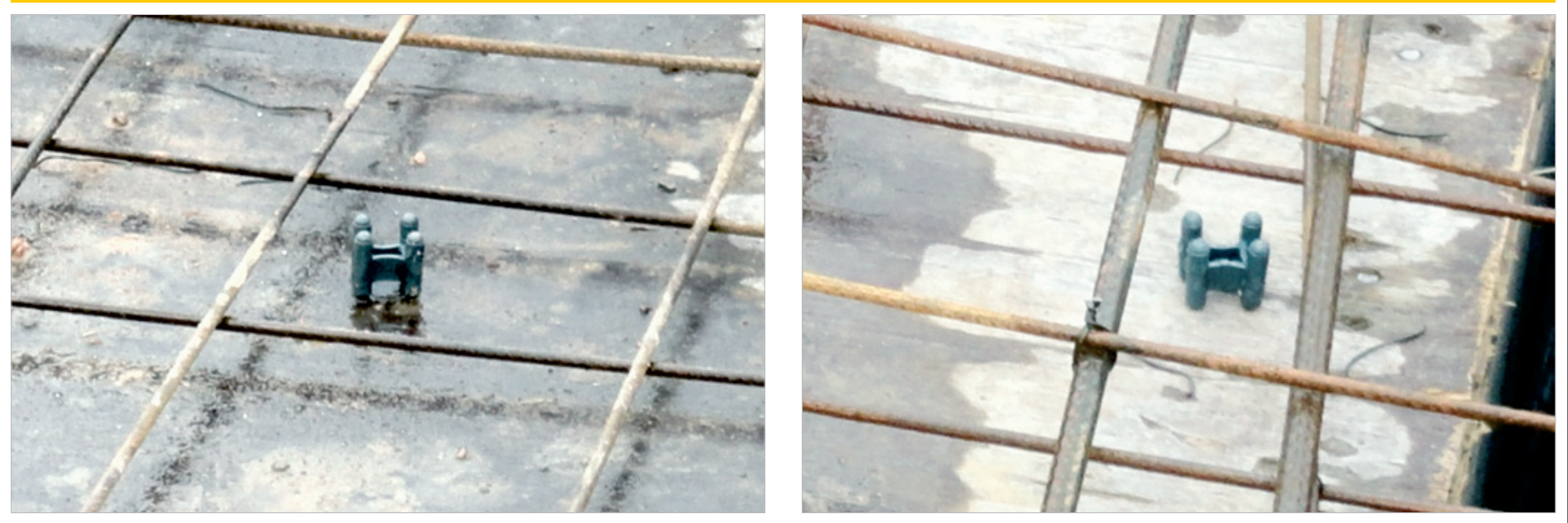


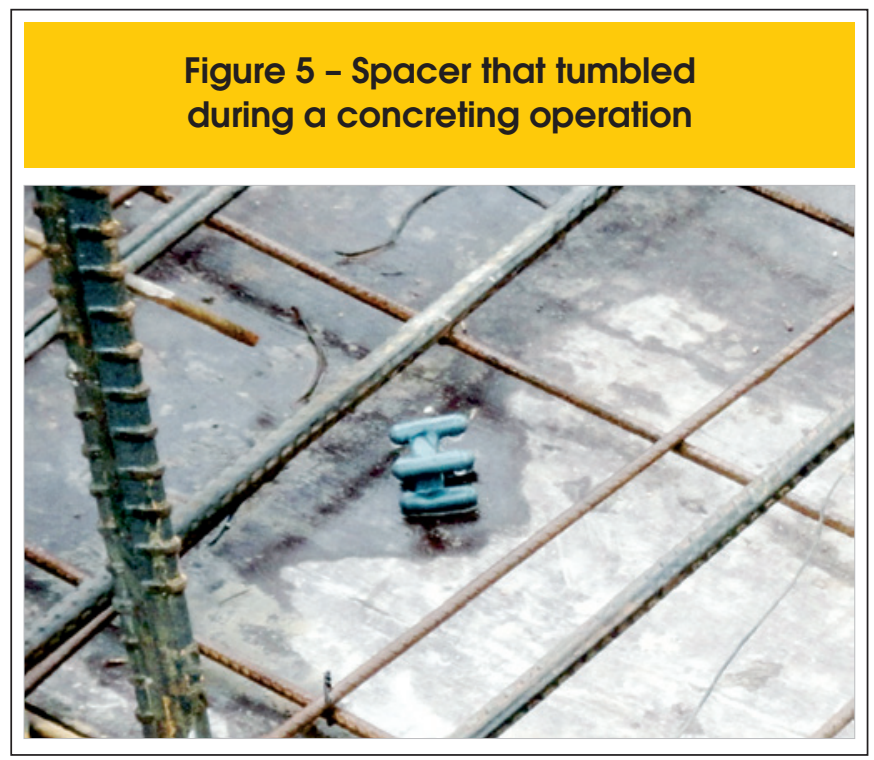

of elements, such as circular spacers. These loads must be resisted under a maximum linear permanent deformation, in the direction of the covering, of $1 \mathrm{~mm}$ [11][12], avoiding situations such as in Figure 6.

\subsection{Application}

The spacer must be easily applicable to steel bars. That way, there is no need for a qualified workforce for its application. To this end, it should not require more than $0,15 \mathrm{kN}$ (load applied by any adult) for their placement on the largest diameter of the bar reported by the manufacturer [11][12].

\section{Experimental program}

After establishing the performance requirements and criteria listed in the previous sub-item, methods for their verification and evaluation are proposed.

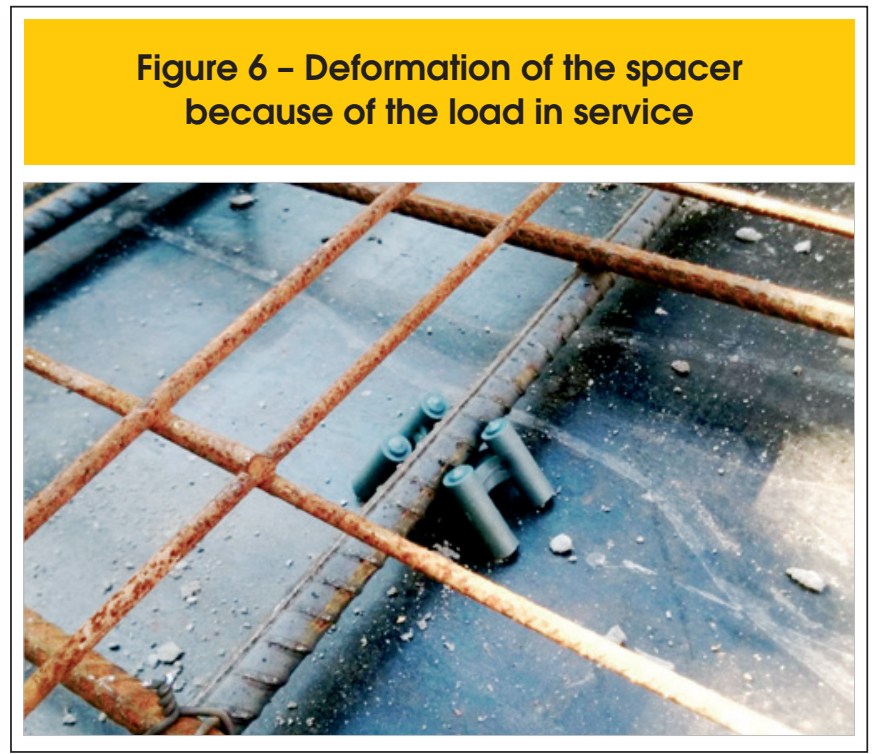

\subsection{Dimensional requirements and criteria}

Although the foreign standards do not say anything about the method of assessment of the dimensional requirements and criteria, the following methods were developed:

a) The method to assess the performance of the requirement "providing a single covering value or at most two clearly identified covering values" consists of a visual inspection and analysis of the product design. The performance is considered satisfactory when the spacer provides only one covering or, in the case of two coverings in the same spacer, these are clearly identified on the product;

b) The method to assess the performance of the requirement "ensuring the nominal covering" consists of a dimensional inspection by applying a steel bar to the spacer, after it is measured the distance $(\mathrm{C})$ between the support base of the spacer and the back of the steel bar, as in Figure 7, immediately before and after the spacer, measured with a digital pachymeter with

Figure 7 - Evaluation method of the design requirement: a) in chair-type spacers; b) in circular spacers
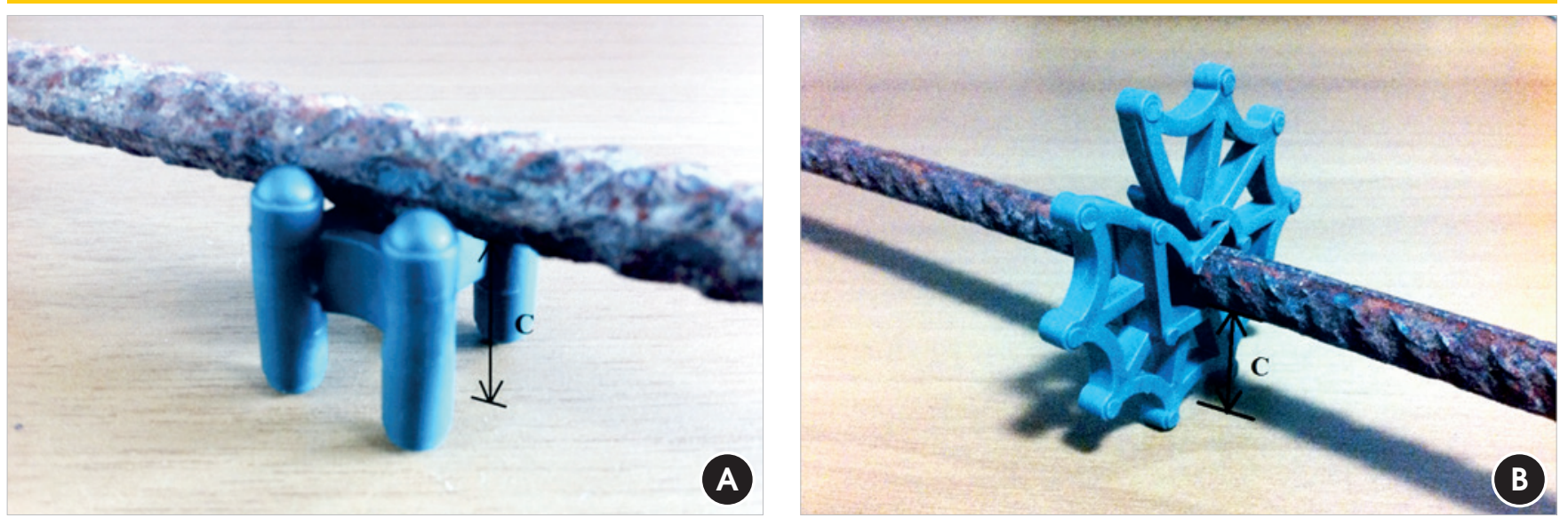


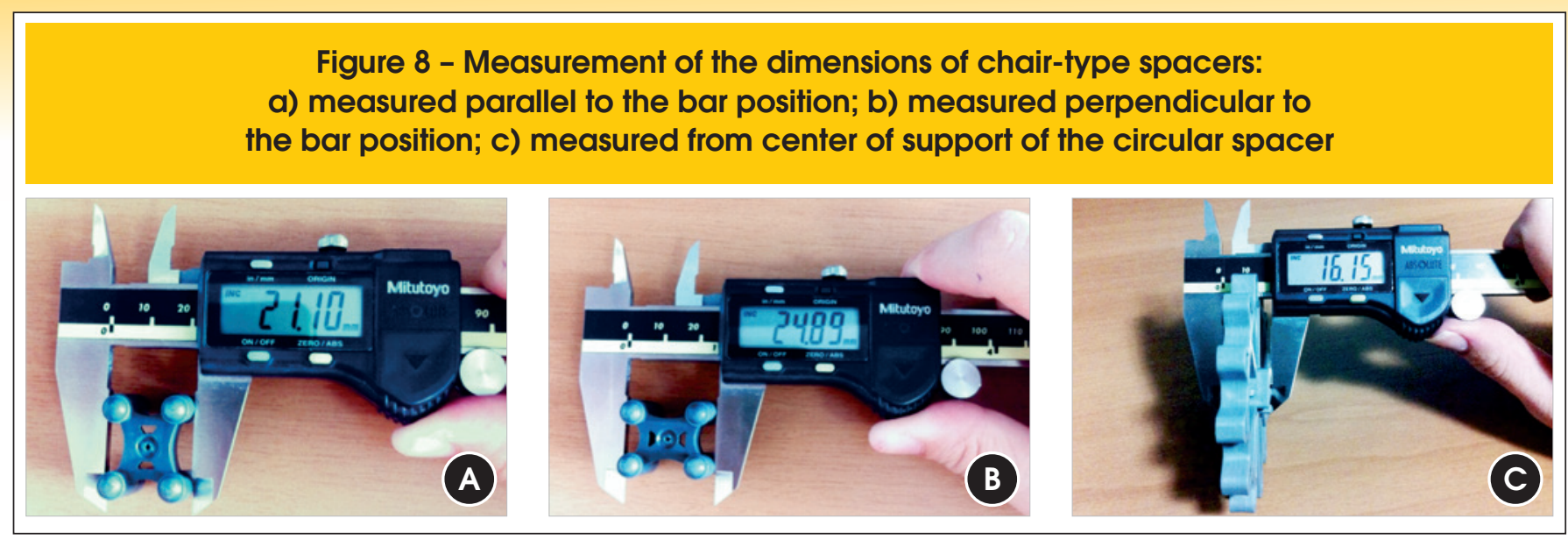

Table 1 - Dimensional parameters for the minimum design requirements (CEB, 1990 and BS 7973-1, 2001)

\begin{tabular}{|c|c|c|}
\hline \multirow{2}{*}{ Model } & \multicolumn{2}{|c|}{ Minimum measure of the base } \\
\hline & Perpendicular to the steel bar & Parallel to the steel bar \\
\hline Chairs and multiple-support spacers & $\geq 0.75$ of the provided cover & $\geq 20 \mathrm{~mm}$ and $\leq 350 \mathrm{~mm}$ \\
\hline Circular Spacers & - & $\geq 0.5$ of the provided cover \\
\hline
\end{tabular}

an accuracy of $0.02 \mathrm{~mm}$. The performance is considered satisfactory when the covering provided by the product is equal to the one specified by the manufacturer, with a tolerance of \pm 1 $\mathrm{mm}$ for coverings up to $75 \mathrm{~mm}$ and $\pm 2 \mathrm{~mm}$ for larger coverings;

c) The method to assess the performance of the requirement "minimum dimensions" also consists of a dimensional inspection which is performed with the aid of a digital pachymeter with an accuracy

Figure 9 - Schematic representation of the spacer mounting test (11)(12)

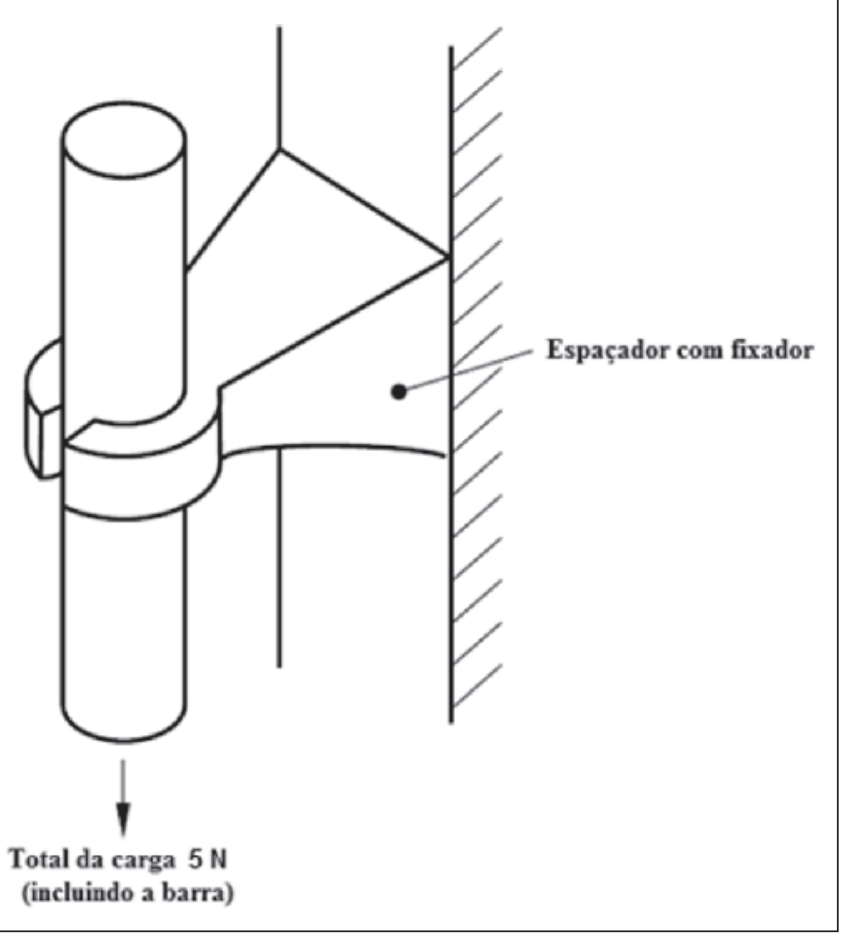

of $0.02 \mathrm{~mm}$, as in Figure 8. The performance is considered satisfactory when the measures meet the values specified in Table 1.

\subsection{Identification requirements and criteria}

The method to assess the performance of this requirement consists in a technical inspection of the product. If it has the nominal cover information visible and a different color than other spacers of the same model, then this is considered to be satisfactory, otherwise it is considered unsatisfactory.

\subsection{Fixity requirements and criteria}

The method of assess the performance of this requirement consists in a technical inspection and analysis of the product design to verify if the spacer has an integrated fixity item. If it does not have some type of integrated mount, then it will automatically be considered unsatisfactory. However, if the product has a fixity item, then the evaluation method will proceed according to the test proposed by the CEB Bulletins \#201 [12] and the British Standard BS 7973-1 [11], which applies a clean steel bar to the spacer with a smaller diameter that should be applied to the spacer according to the manufacturer, with a weight of $5 \mathrm{~N} \pm 0.1 \mathrm{~N}$, as in Figure 9 . If the spacer prevents slippage of the bar, then this is considered satisfactory, otherwise it is considered unsatisfactory. The parameter of the assessment method does not contemplate tolerances.

\subsection{Stability requirements and criteria}

The method to assess the performance of this requirement consists in dimensional inspections with the aid of a digital pachymeter with an accuracy of $0.02 \mathrm{~mm}$, as specified in CEB Bulletins \#201 [12] and British Standard BS 7973-1 [11].

For a clip-on spacers, except for circular spacers, the stability is considered ensured when a the spacer provide rotating radius at least $5 \mathrm{~mm}$ larger than the required cover. This radius should be provided by the spacer in the parallel and perpendicular dimensions to the 
steel bar to which it is applied, as in Figure 10 (a, b and c).

Circular spacers do not require a minimum radius of perpendicular rotation to the bar, since the stability is provided by the width of the central support parallel to the bar, which must be greater than half the covering provided, as shown in Figure 10d.

Spacers that do not possess a fixity item or do not meet the parameters and performance criteria described are considered to be unsatisfactory.

\subsection{Load capacity requirements and criteria}

The assessment of the load capacity requirement is an adaptation of the method proposed by CEB Bulletins \#201 [12] and British Standard BS 7973-1 [11], which consists of a laboratory test. In order for the test to be performed, the first device in Figure 11 was developed, in which a steel bar of $8 \mathrm{~mm}$ from the device is applied to the spacer, just as in Figure 12. Afterwards, the assembly (device + spacer) is placed into a press and a force is applied until reaching the load capacity required for the spacer according to Table 2 .

After the test is interrupted, either because of a rupture or because the load capacity is reached, the assembly is removed from the press and the maximum linear permanent deformation in the direction of the covering is measured, which must be less than $1 \mathrm{~mm}$. The press program generated stress versus deformation graphs concerning the behavior of the material.

Spacers that allow for two distinct coverings should be tested in their most unfavorable position, i.e., applied on the device according to the largest provided covering. Those products are considered satisfactory when that meet the established performance criteria.

Figure 10 - Geometrical stability requirements for spacers with integrated mount (11)(12):

a) rotation radius parallel to the steel bar; b) rotation radius parallel to the steel bar; c) rotation radius perpendicular to the steel bar; d) width of the central support of circular spacers

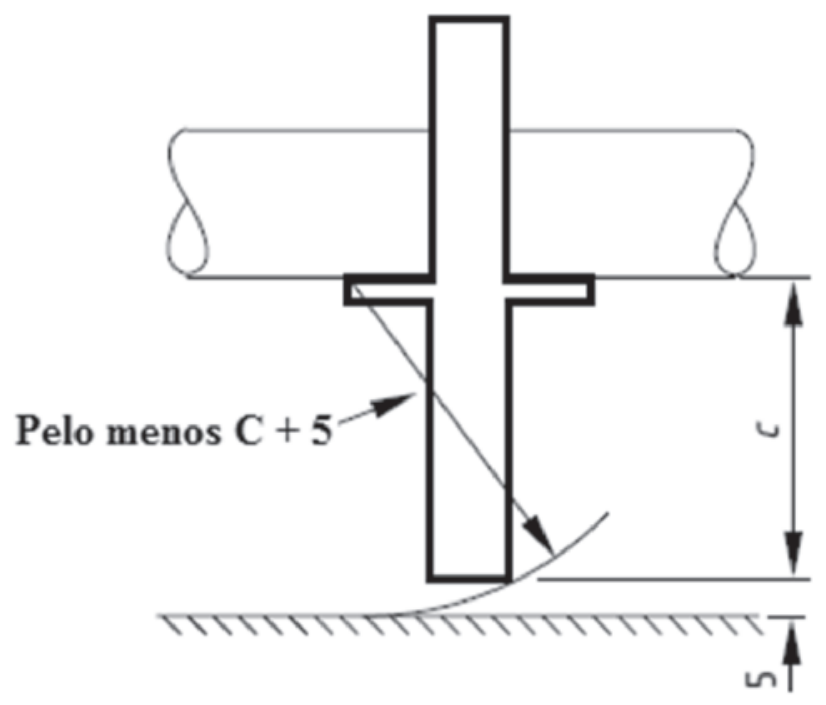

A

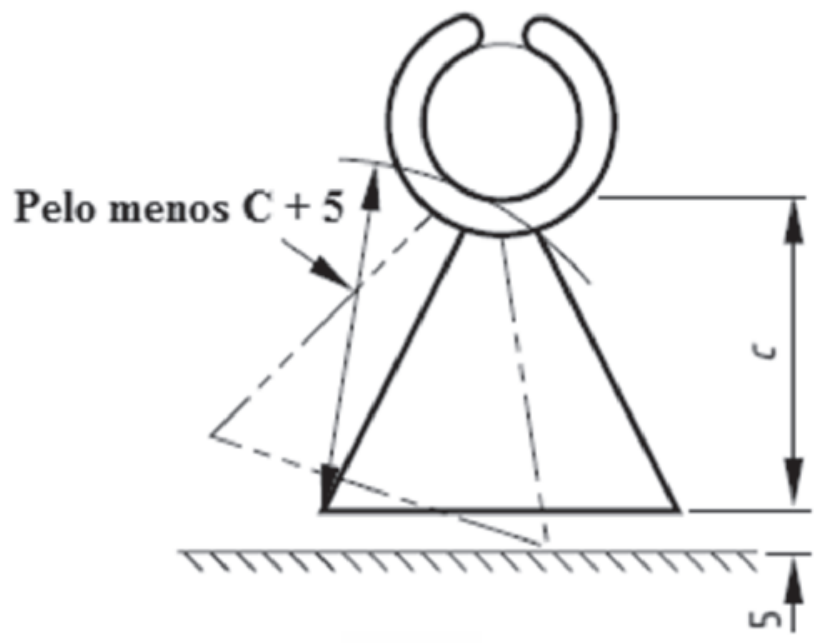

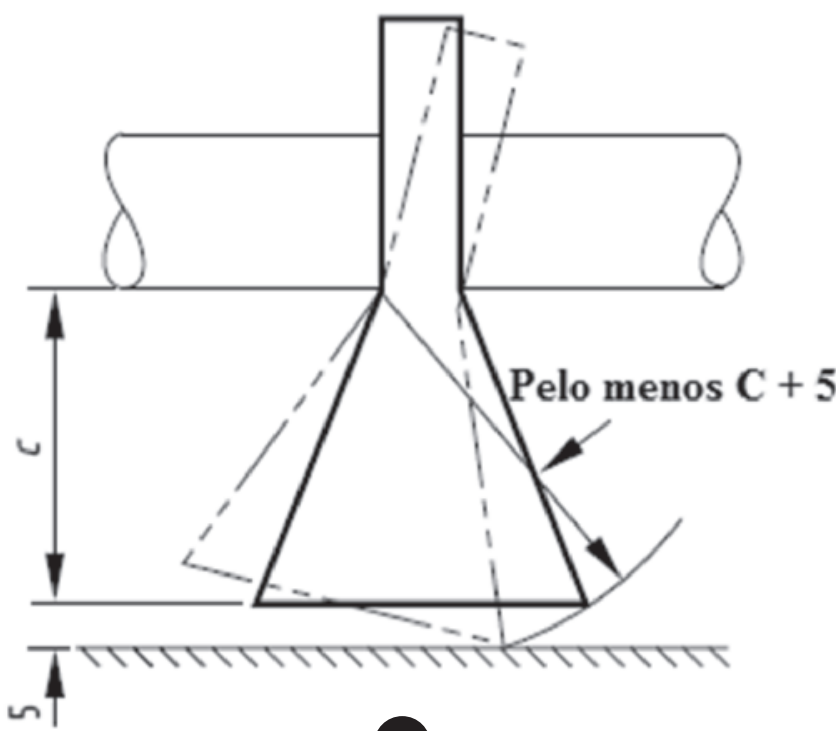

B

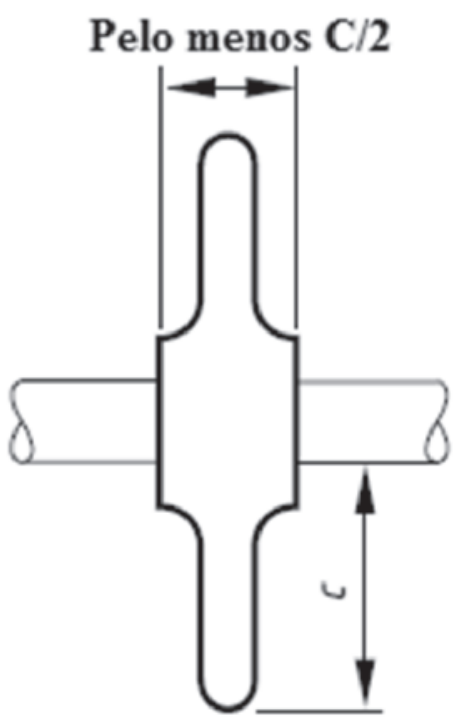


Figure 11 - Devices developed to evaluate the performance:

a) load capacity requirement; (b) mounting requirement

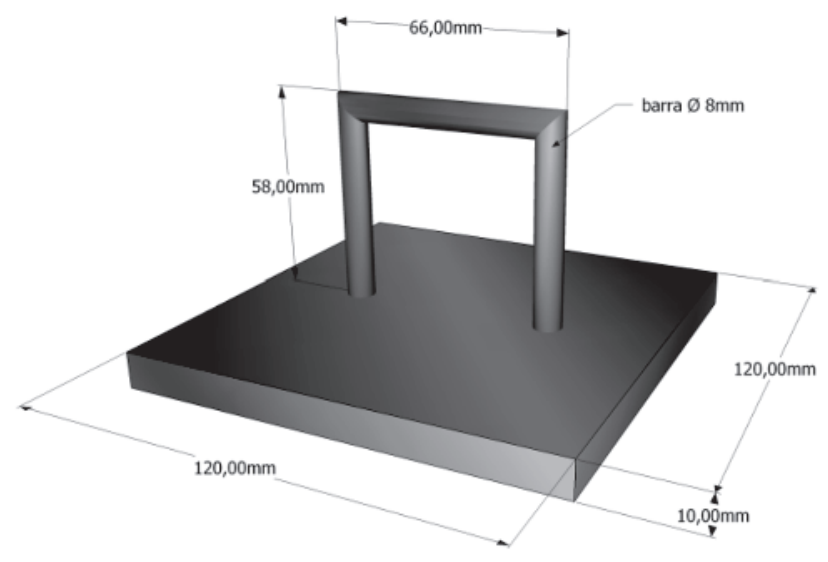

A

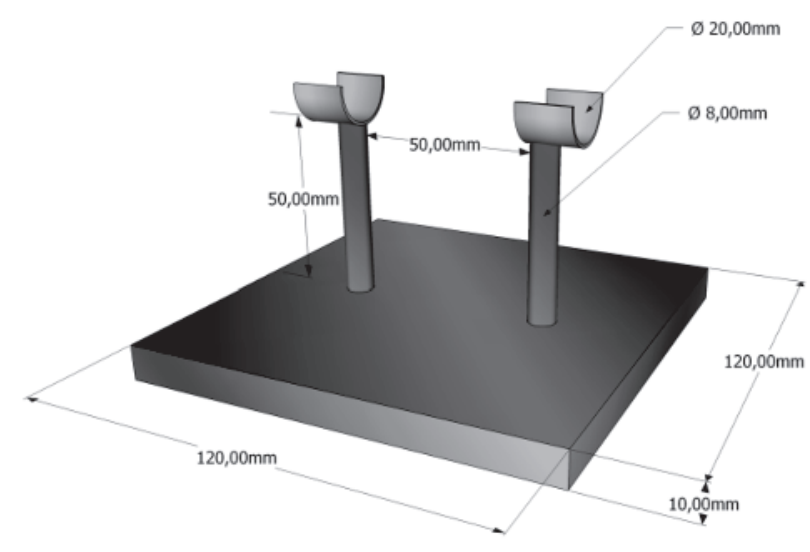

B

Figure 12 - Load capacity test: a) in circular spacers; b) in chair-type spacers

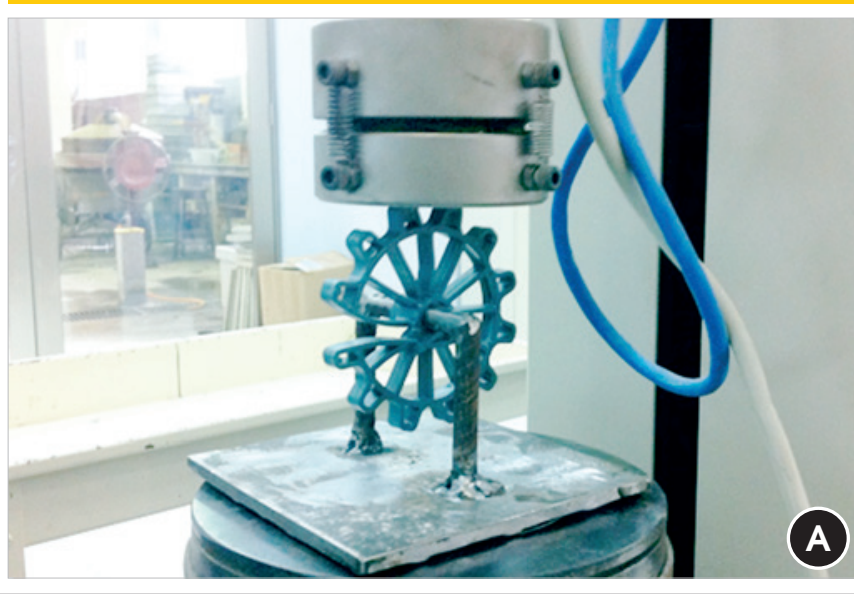

Although the CEB Bulletins \#201 [12] and the British Standard BS 7973-1 [11] use a different method for this assessment (Figure 13), the test proposed above was designed in order to obtain graphs generated by the press on material behavior regarding its stress and deformation.

\subsection{Application requirements and criteria}

The method to assess the performance of this requirement consists of a laboratory test in which the spacer is supported on the

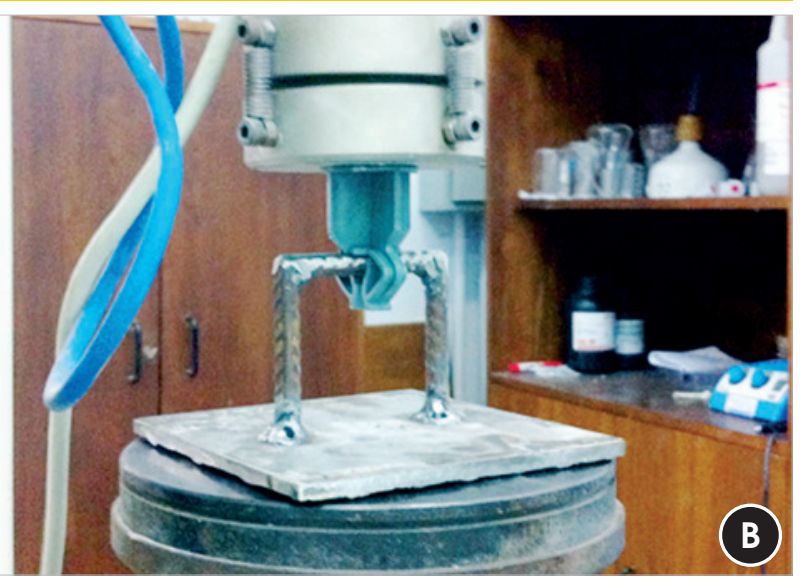

largest bar diameter recommended by its manufacturer. The assembly is then inserted in a press, as in Figure 14, and the load is applied until the complete fit of the spacer on the steel bar.

The product is considered satisfactory when no more than $0,15 \mathrm{kN}$ of force is required for its full application.

Although the CEB Bulletins \#201 [12] and the British Standard BS 7973-1 [11] do not indicate a specific method to evaluate this requirement, the proposed test was designed in order to have a method to assess this requirement. As such, a second device was developed as specified in Figure 11.

\begin{tabular}{|c|c|c|}
\hline \multicolumn{3}{|c|}{$\begin{array}{l}\text { Table } 2 \text { - Parameters for the maximum load value applied in the } \\
\text { test of the assessment method of the load capacity requirement }\end{array}$} \\
\hline Spacer & Demand & Load capacity \\
\hline Chair and multiple - support spacers & Heavy & $3.0 \mathrm{kN}$ \\
\hline Circular spacers & Light & $0.25 \mathrm{kN}$ \\
\hline
\end{tabular}


Figure 13 - Apparatus for testing the load capacity (11)(12)

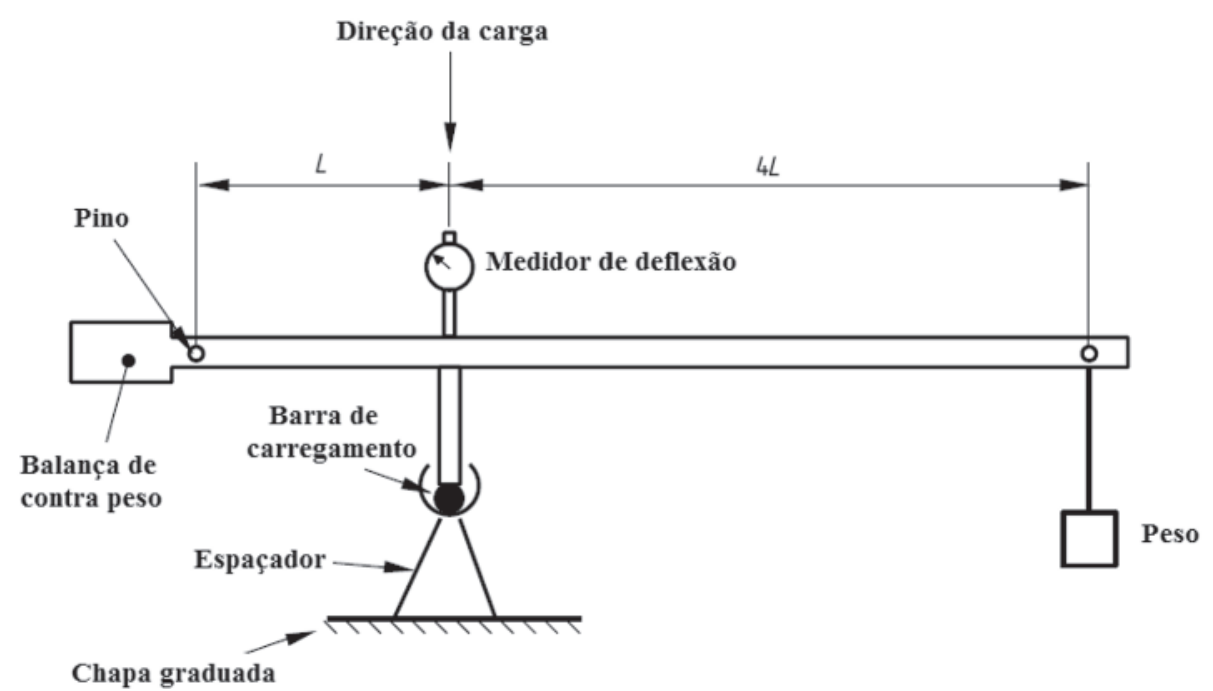

Figure 14 - Spacer application test to the steel bar: a) in circular spacers; b) in chair-type spacers
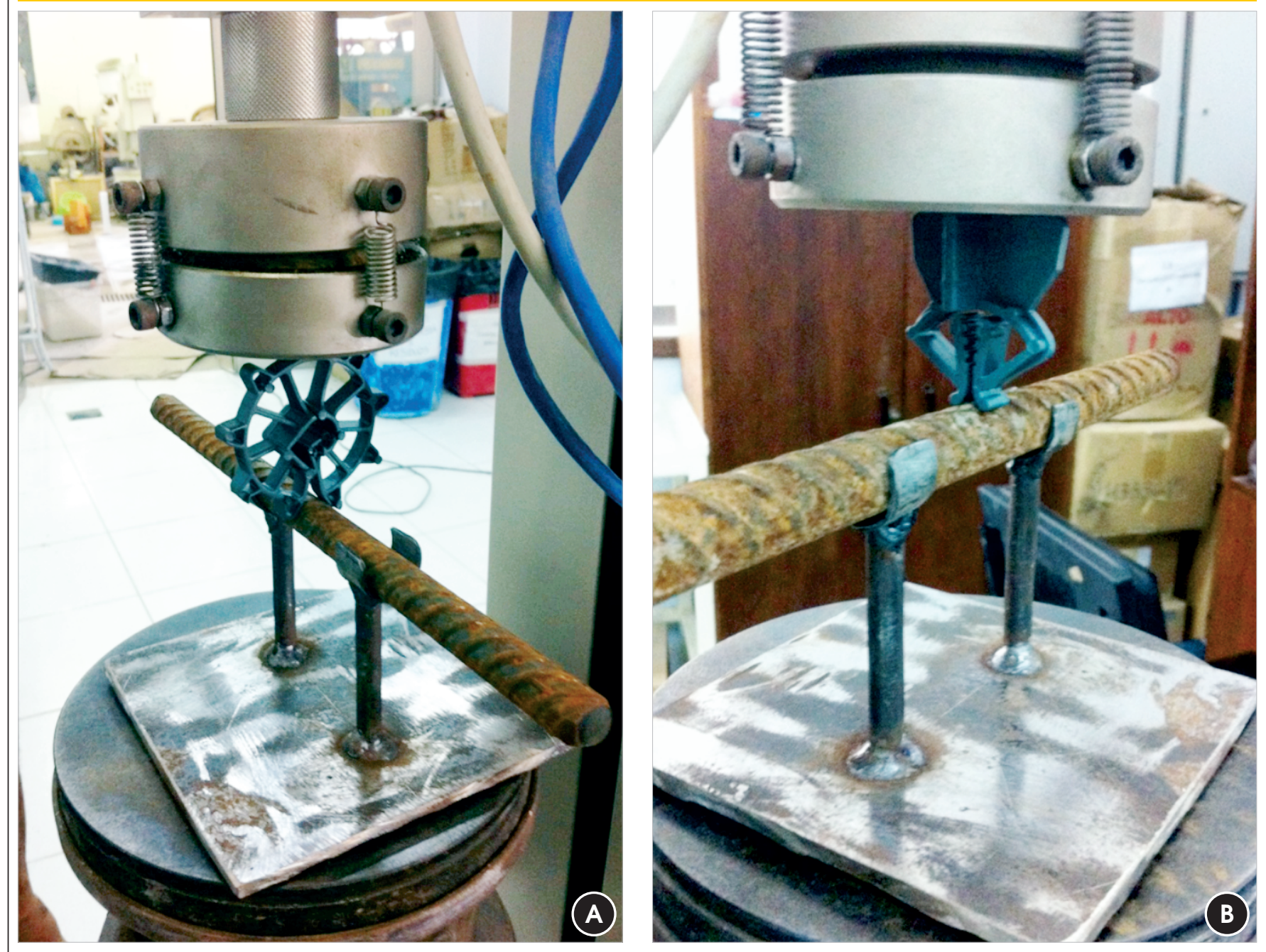


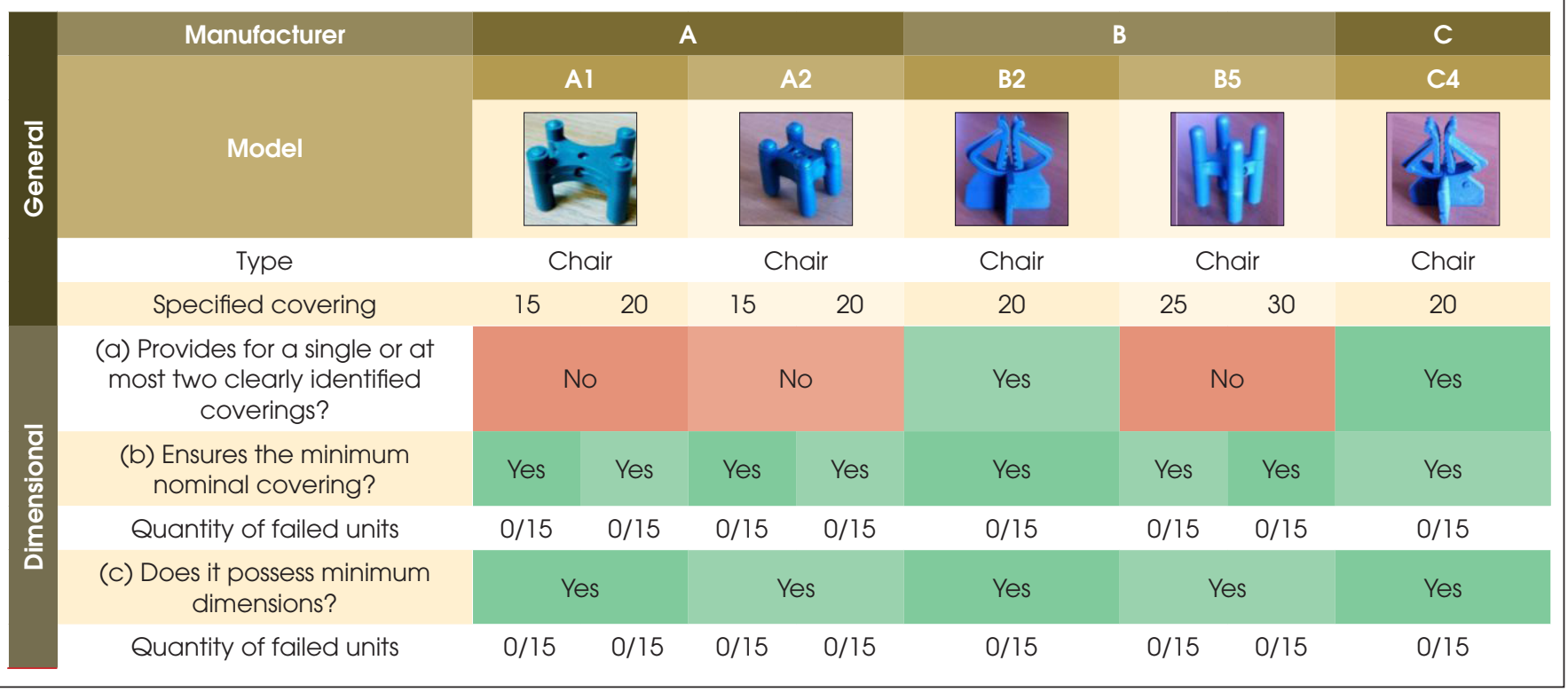

\subsection{Validation of the evaluation methods for the assessment of spacer performance}

In order to validate the proposed evaluation methods, 18 spacer models of 5 distinct manufacturers (A, B, C, D and E) and 10 more models of unidentified suppliers $(X)$ were tested. All spacers were obtained from construction works that cooperated with the study and consist of 10 chair, 13 circular and 5 multiple-support spacer models.

Following the CEB Bulletins \#201 [12] criteria, a minimum of 10 units of each specific model were tested in accordance with the proposed assessment method, and with at least $90 \%$ of the units

Whenever a sample (of at least 10 units of the product) failed to meet the requirements specified above, the whole batch of spac-

\section{Table 4 - Results of the design requirement evaluation of the chair-type spacers of the manufacturer $E$ and of unknown manufacturers}

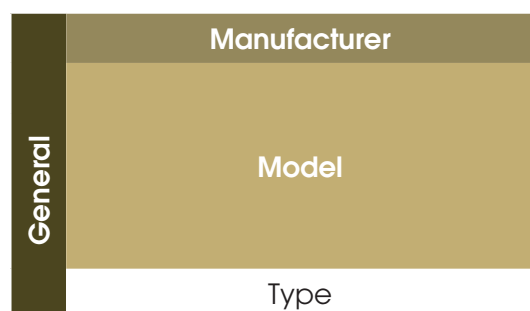

Specified covering

(a) Provides for a single or at most two clearly identified coverings?

(b) Ensures the minimum nominal covering?

Quantity of failed units

(c) Does it possess minimum dimensions?

Quantity of failed units

\section{Table 3 - Results of the design requirement evaluation of} the chair-type spacers of the manufacturers A, B and C having to meet the proposed requirements. ers was rejected and considered unsatisfactory.

\section{Results and discussion}

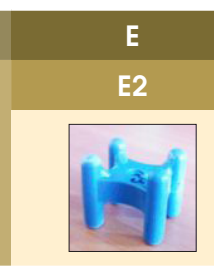

Chair

$15 \mid 20$

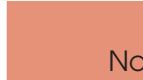

No

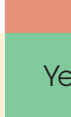

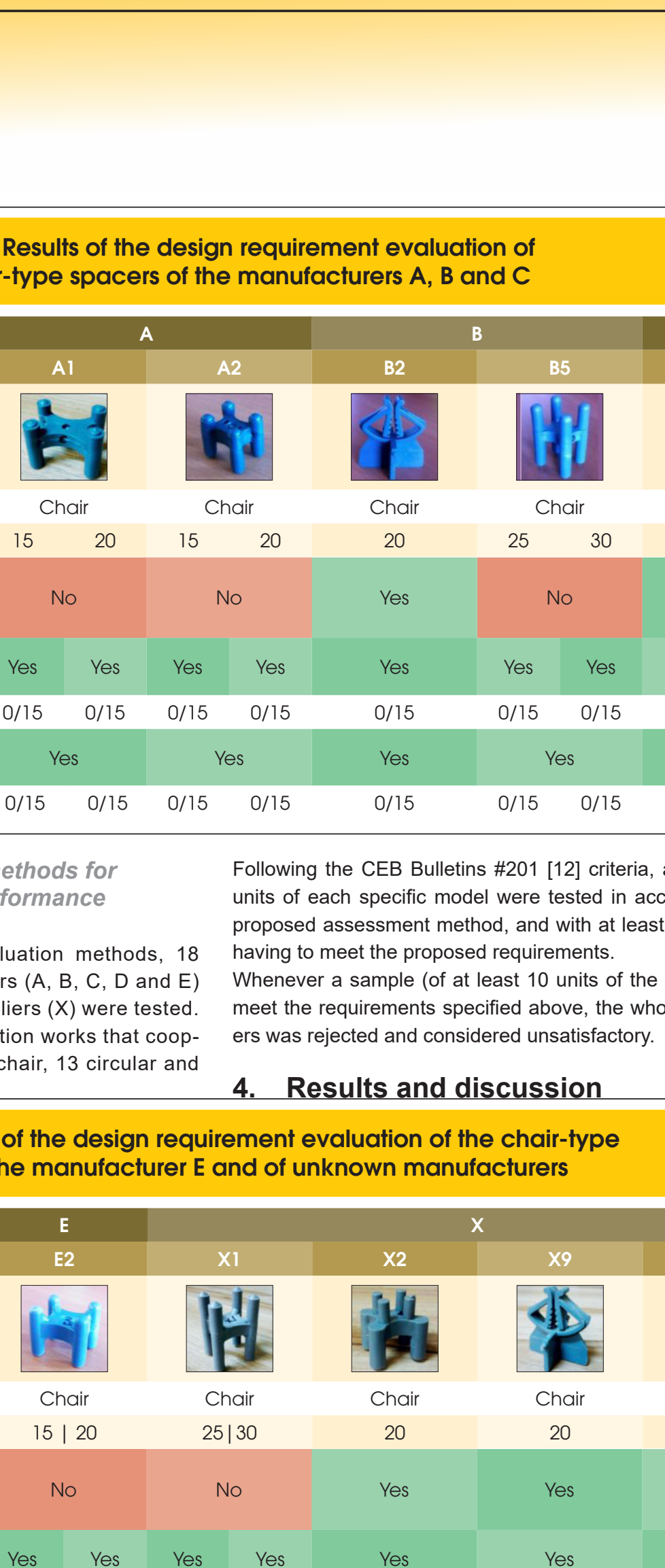

$\mathrm{X} 10$

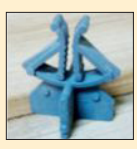

Chair

20

Yes

Sim

$0 / 15$

$\begin{array}{lllllll}0 / 15 & 0 / 15 & 0 / 15 & 0 / 15 & 0 / 15 & 0 / 11 & 0 / 15\end{array}$

\begin{tabular}{|ccccccc|}
\multicolumn{2}{c}{ Yes } & \multicolumn{2}{c}{ Yes } & Yes & Yes & Yes \\
\hline $0 / 15$ & $0 / 15$ & $0 / 15$ & $0 / 15$ & $0 / 15$ & $0 / 11$ & $0 / 15$ \\
\hline
\end{tabular}




\section{Table 5 - Results of the design requirement evaluation of the circular-type spacers of the manufacturers A, B and C}

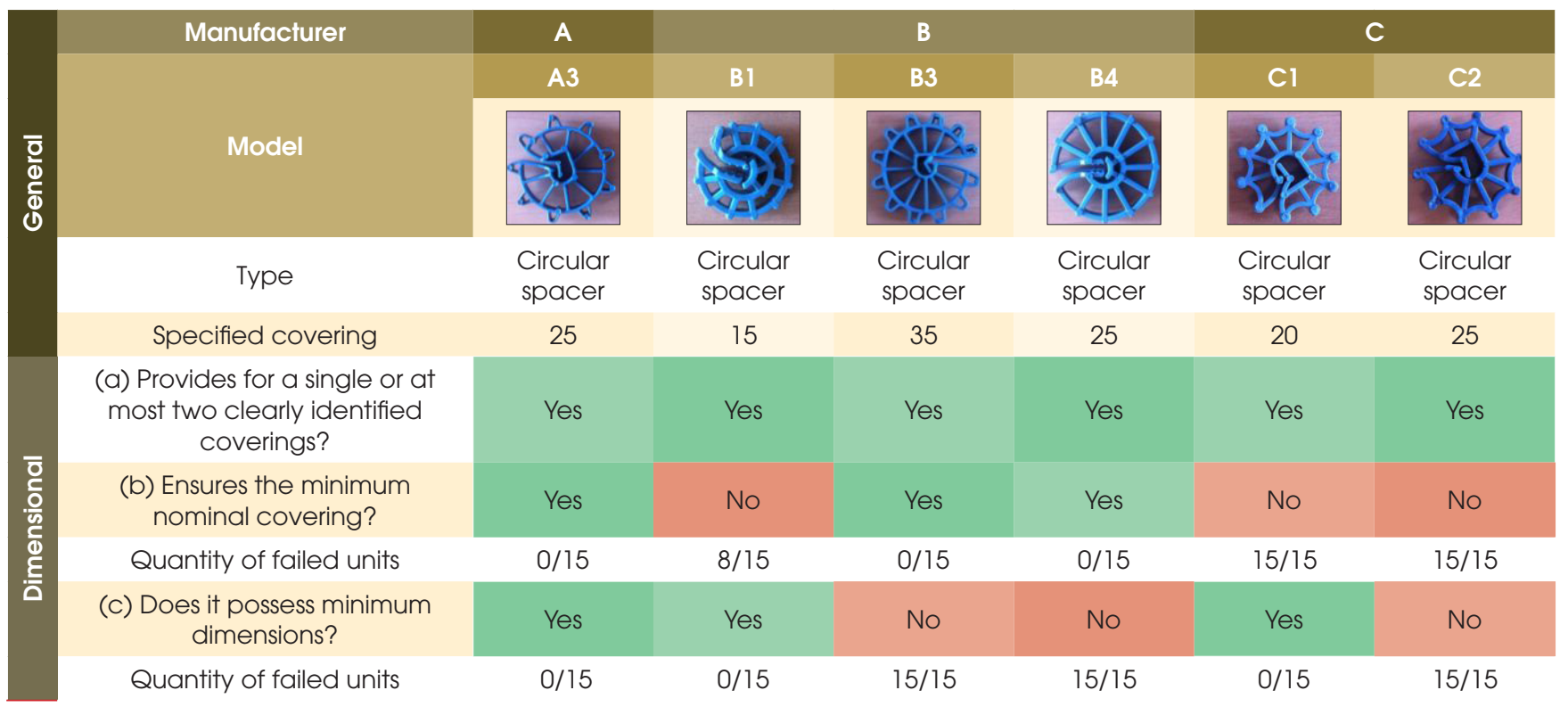

In this section, the results obtained per requirement are presented and discussed.

\subsection{Dimensional}

In Table 3 and Table 4 the performance assessments of the chair-type spacers can be found. They reveal that the models $A 1, A 2, B 5, E 2$ and $X 1$ didn't satisfy the first design requirement. All the chair-type spacers were approved in the evaluation of the second and third design requirements, however. For the circular spacers, the results of the performance assessments of the design requirement can be seen in Table 5 and Table 6. One can see that all models were approved in the first design requirement. In the second requirement, on the other hand, only models A3, B3, B4, D3 and E1 proved satisfactory results. In the last design requirement, only the models $\mathrm{B} 3, \mathrm{~B} 4, \mathrm{C} 2$, D3 and $\mathrm{X} 3$ were rejected. The performance evaluation of multi-support spacers can be read in Table 7, which reveals that all models had satisfactory results for the first and third design requirement. However, in the evaluation of the second design requirement, only the models D1 and D2 were rejected and thus considered as unsatisfactory.

Of the 28 evaluated spacer models, therefore, 10 were approved for all design requirements $(B 2, C 4, X 2, X 9, X 10, A 3, E 1, C 3, E 3$

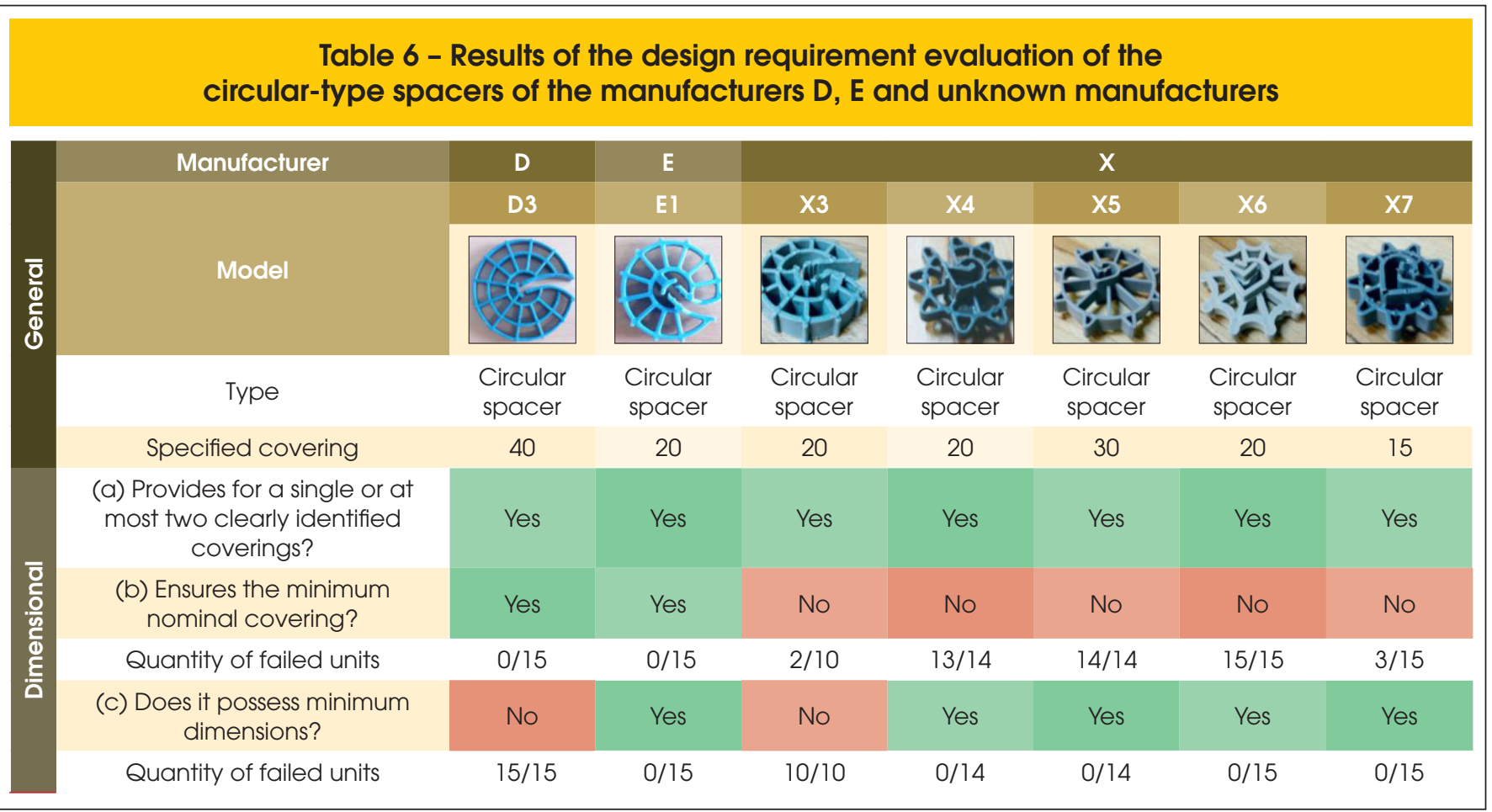




\section{Table 7 - Results of the design requirement evaluation of the multi-support-type spacers of the manufacturers $C, D, E$ and unknown manufacturers}

\begin{tabular}{|c|c|c|c|c|c|}
\hline Manufacturer & C & & & E & $\mathbf{x}$ \\
\hline \multirow[b]{2}{*}{ Model } & C3 & D1 & D2 & E3 & X8 \\
\hline & $60.13=$ & 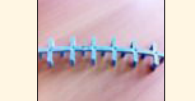 & Qving & & \\
\hline Type & Multi-support & Multi-support & Multi-support & Multi-support & Multi-support \\
\hline Specified covering & 25 & 15 & 20 & 25 & 25 \\
\hline $\begin{array}{c}\text { (a) Provides for a single or at } \\
\text { most two clearly identified } \\
\text { coverings? }\end{array}$ & Yes & Yes & Yes & Yes & Yes \\
\hline $\begin{array}{l}\text { (b) Ensures the minimum } \\
\text { nominal covering? }\end{array}$ & Yes & No & No & Yes & Yes \\
\hline Quantity of failed units & $0 / 12$ & $15 / 15$ & $15 / 15$ & $0 / 15$ & $0 / 15$ \\
\hline $\begin{array}{c}\text { (c) Does it possess minimum } \\
\text { dimensions? }\end{array}$ & Yes & Yes & Yes & Yes & Yes \\
\hline Quantity of failed units & $0 / 12$ & $0 / 15$ & $0 / 15$ & $0 / 15$ & $0 / 15$ \\
\hline
\end{tabular}

and $\mathrm{X} 8$ ) and the other 18 were considered unsatisfactory in at least one evaluation for this requirement.

\subsection{Identification}

In the evaluation of the identification requirement, no evaluated spacer model had the nominal covering on the product itself.

With respect to the color differentiation in a same model, but with different coverings, none of the identified manufacturer (A, B, C, D and $\mathrm{E}$ ) provided this distinction between their models. The same cannot be said for the unidentified manufacturers (unknown manufacturers), because as the producer was unknown, the products of the same model could not be tracked down.

Although no evaluated model satisfied this requirement, there are spacers that would be approved in the assessment, as shown in Figure 15. These were not assessed, however, because the sample was insufficient for evaluation.

\subsection{Fixity}

As none of the evaluated models provided a manufacturer's specification in relation to the minimum reinforcement diameter to which the spacers could be applied, the smallest diameter allowed for brackets was adopted, $5 \mathrm{~mm}$ according to ABNT NBR 6118 [17].

Table 8 and Table 9 show the mounting requirement evaluations for the chair model. Although the models B2, C4, X9 and X10 had a mounting item, it was not able to prevent the slipping of the steel bar. No model satisfactorily met the requirements and criteria established, therefore, with all being rejected according the proposed evaluation method.

For the circular models, on the other hand, the result of the evaluation can be found in Table 10 and Table 11. As the circular models have a mounting item, all were tested and most were approved. Models D3 and X3 were rejected, however, because they didn't resist the displacement of the steel bar.

Just as the chair-type spacers, all multi-support models failed this performance test. The unsatisfactory performance was established immediately as none possessed a mounting item, as can be seen in Table 12.

\section{Figure 15 - Spacers that meet the identification requirement}
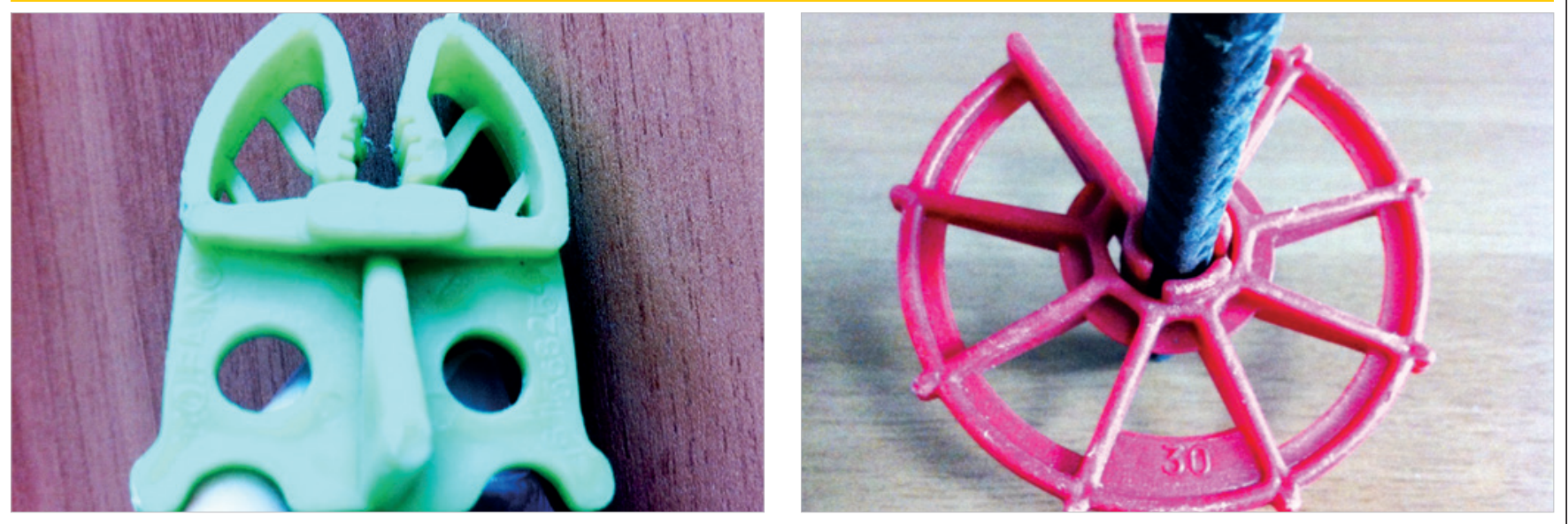
Table 8 - Results of the fixity requirement evaluation of

the chair-type spacers of the manufacturers A, B and C

\begin{tabular}{|c|c|c|c|c|c|}
\hline Manufacturer & \multicolumn{2}{|c|}{ A } & \multicolumn{2}{|c|}{ B } & C \\
\hline \multirow[b]{2}{*}{ Model } & Al & A2 & B2 & B5 & $\mathrm{C} 4$ \\
\hline & & & & & \\
\hline Type & Chair & Chair & Chair & Chair & Chair \\
\hline Specified covering & 15 | 20 & 15 | 20 & 20 & $25 \mid 30$ & 20 \\
\hline $\begin{array}{c}\text { Does it have an integrated } \\
\text { mounting item? }\end{array}$ & No & No & Yes & No & Yes \\
\hline $\begin{array}{c}\rightarrow \text { If yes, it prevents slippage } \\
\text { of the bar? }\end{array}$ & $\mathrm{N} / \mathrm{A}$ & N/A & No & N/A & No \\
\hline Quantity of failed units & $15 / 15$ & $15 / 15$ & $3 / 15$ & $15 / 15$ & $4 / 15$ \\
\hline
\end{tabular}

\section{Table 9 - Results of the fixity requirement evaluation of the chair-type spacers of the manufacturer $E$ and of unknown manufacturers}

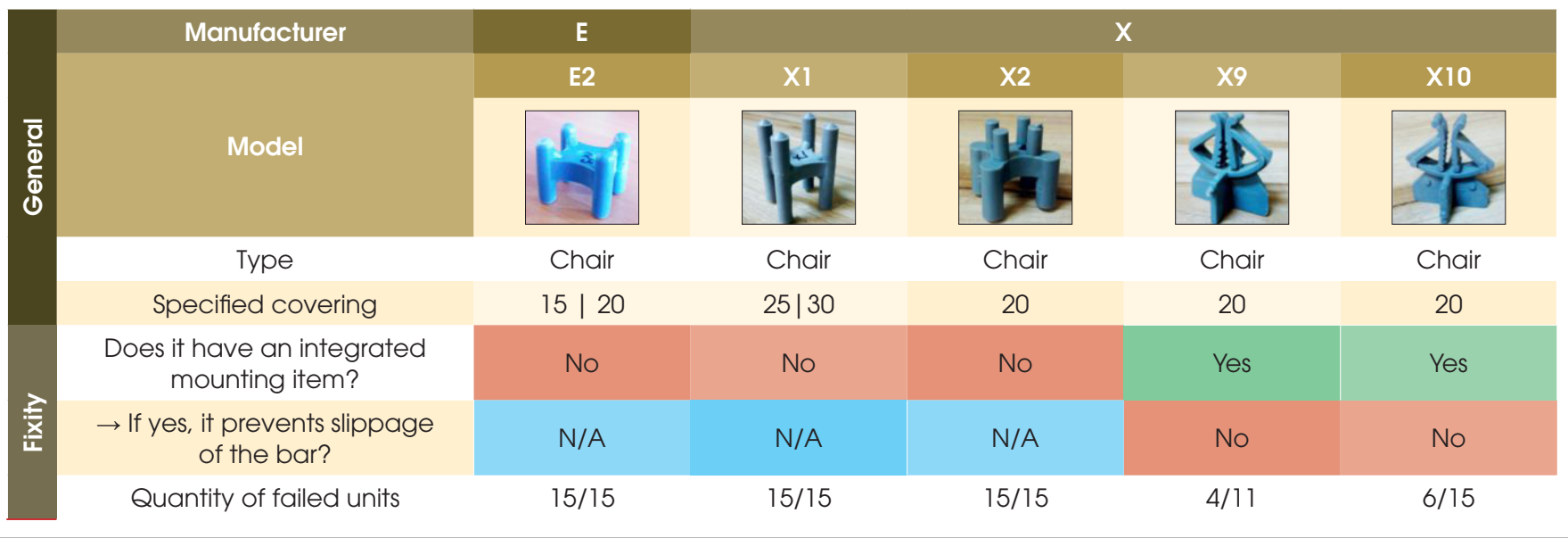

Table 10 - Results of the fixity requirement evaluation of
the circular-type spacers of the manufacturers A, B and C
Manufacturer




\section{Table 11 - Results of the fixity requirement evaluation of the circular-type} spacers of the manufacturers $D, E$ and unknown manufacturers

\begin{tabular}{|c|c|c|c|c|c|c|c|}
\hline Manufacturer & D & E & & & $\mathrm{x}$ & & \\
\hline \multirow[b]{2}{*}{ Model } & D3 & E1 & $\mathrm{X} 3$ & $\mathrm{X} 4$ & $\times 5$ & X6 & X7 \\
\hline & & & & & & & \\
\hline Type & $\begin{array}{l}\text { Circular } \\
\text { spacer }\end{array}$ & $\begin{array}{l}\text { Circular } \\
\text { spacer }\end{array}$ & $\begin{array}{l}\text { Circular } \\
\text { spacer }\end{array}$ & $\begin{array}{l}\text { Circular } \\
\text { spacer }\end{array}$ & $\begin{array}{l}\text { Circular } \\
\text { spacer }\end{array}$ & $\begin{array}{l}\text { Circular } \\
\text { spacer }\end{array}$ & $\begin{array}{l}\text { Circular } \\
\text { spacer }\end{array}$ \\
\hline Specified covering & 40 & 20 & 20 & 20 & 30 & 20 & 15 \\
\hline $\begin{array}{c}\text { Does it have an integrated } \\
\text { mounting item? }\end{array}$ & Yes & Yes & Yes & Yes & Yes & Yes & Yes \\
\hline $\begin{array}{c}\rightarrow \text { If yes, it prevents slippage } \\
\text { of the bar? }\end{array}$ & No & Yes & No & Yes & Yes & Yes & Yes \\
\hline Quantity of failed units & $15 / 15$ & $0 / 15$ & $10 / 10$ & $0 / 14$ & $0 / 14$ & $0 / 15$ & $1 / 15$ \\
\hline
\end{tabular}

Table 12 - Results of the fixity requirement evaluation of the multi-support-type spacers of the manufacturers $C, D, E$ and unknown manufacturers

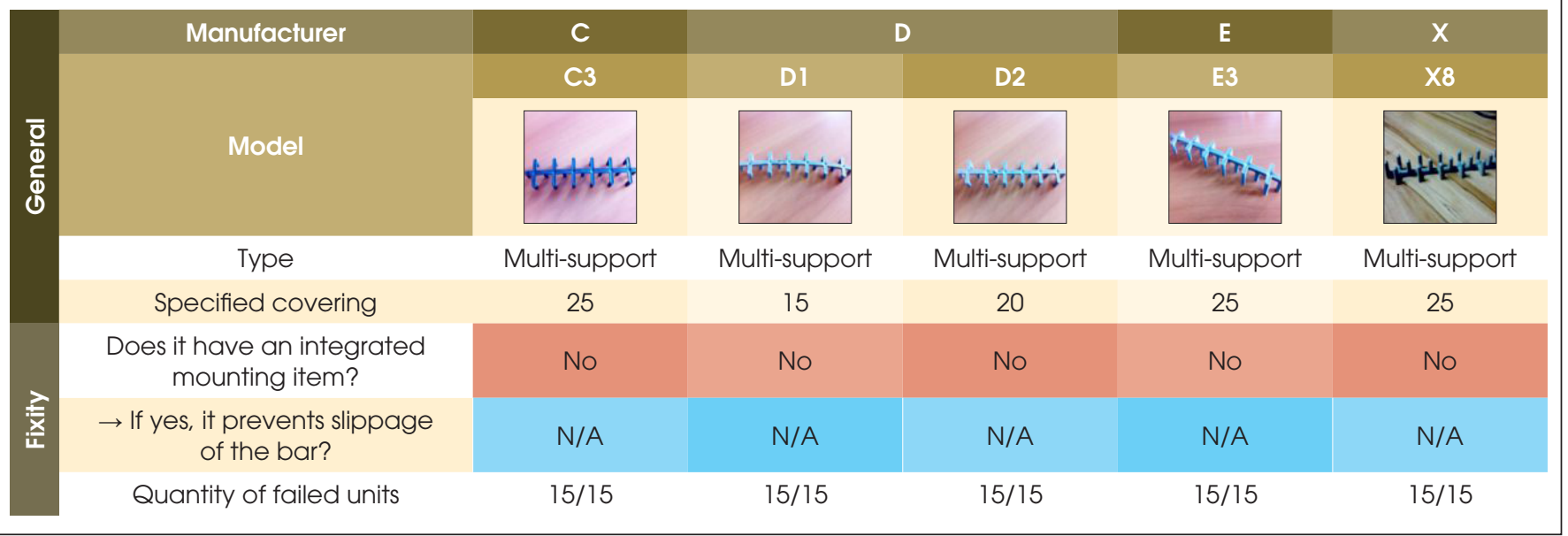

Table 13 - Results of the stability requirement evaluation of the chair-type spacers of the manufacturers A, B and C

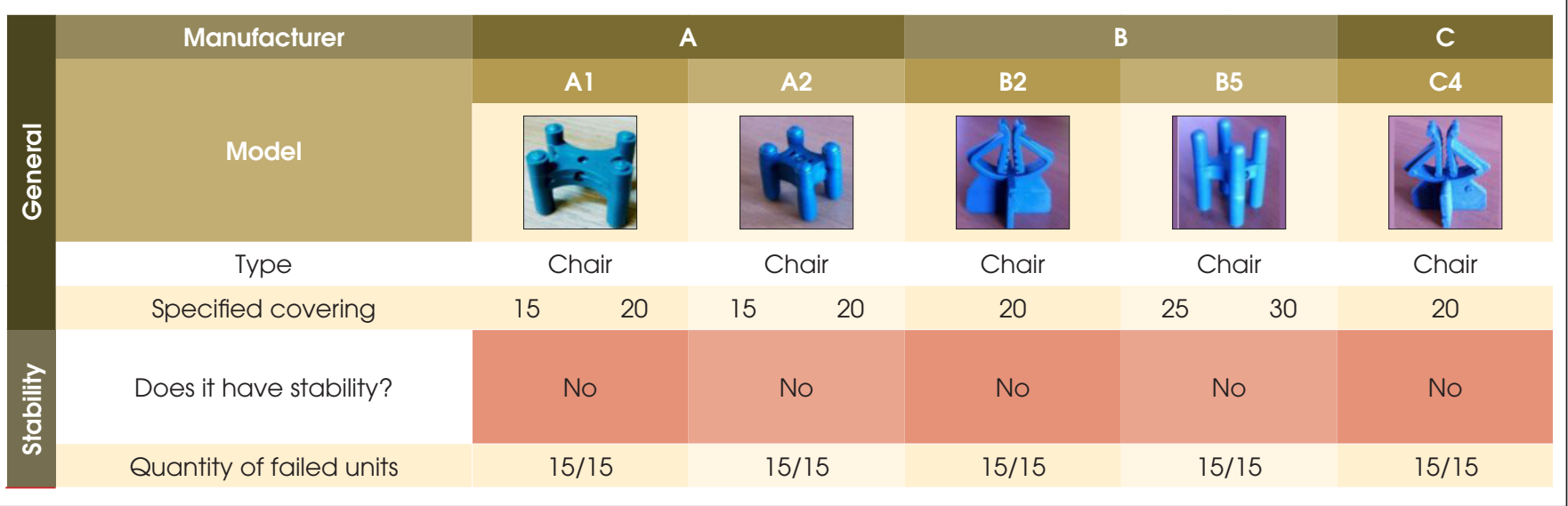




\section{Table 14 - Results of the stability requirement evaluation of the chair-type spacers of the manufacturer $E$ and of unknown manufacturers}

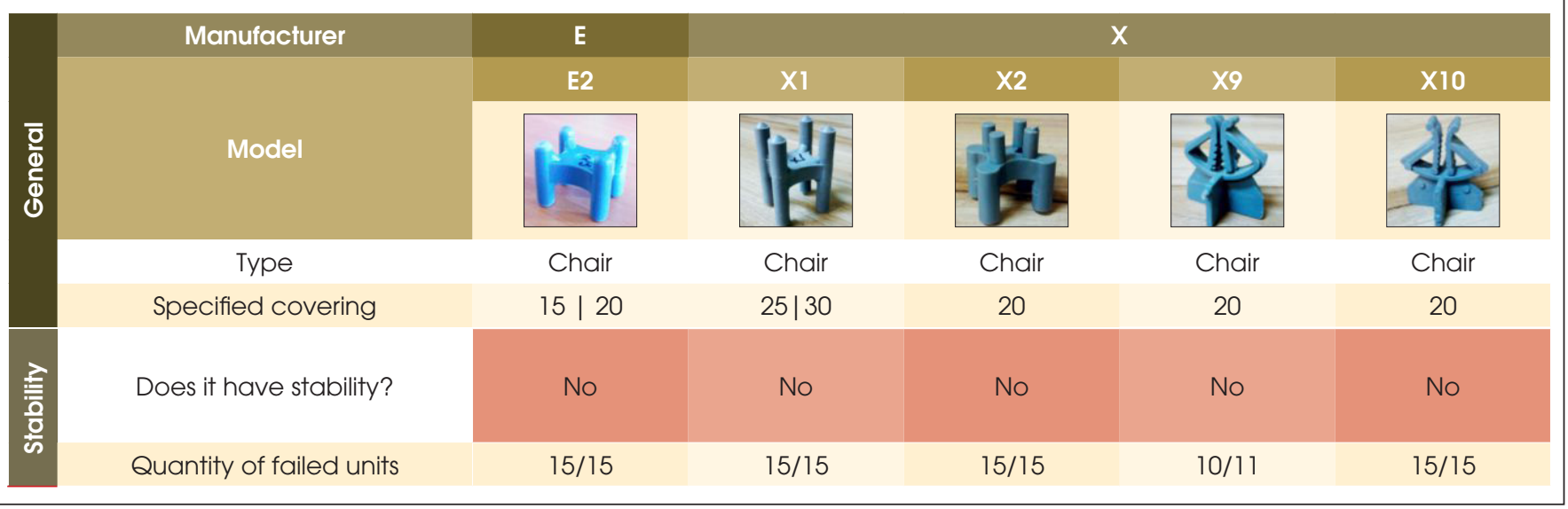

In general, of the 28 evaluated spacer models in the mounting requirement, only 17 models had a mounting item, of which only 11 (A3, B1, B3, B4, C1, C2, E1, X4, X5, X6 and X7) were approved.

\subsection{Stability}

For the stability requirement, the results of the evaluations of the chair-type spacers are displayed in Table 13 and Table 14. As informed, no model was approved according to the proposed evaluation method.

Although all circular model possess a mounting item, which is essential for stability, only models A3, B1, C1, E1, X4, X5, X6 and X7 were approved according to the proposed evaluation method. The other circular models had an unsatisfactory performance, according to Table 15 and Table 16.

As they didn't have a mounting item, the multi-support models were not even evaluated, being automatically considered as unsatisfactory, as can be seen in Table 17.

In short, the stability requirement evaluation resulted in 8 approved models and 20 rejected models according to the proposed evaluation method.

\subsection{Load capacity}

As defined, the assessment of this requirement is dependent on two variables: resisted load capacity and maximum permanent linear deformation. For chair-type models, the results can be seen in Table 18 and Table 19

One can see that of the 10 models evaluated, only 2 (B2 and X9) showed a satisfactory performance in this requirement, while the remainder was considered unsatisfactory.

In Table 20 and Table 21 the load capacity results for the circular models can be seen.

Although most circular spacers resisted the minimum load required, many had a permanent linear deformation that exceeded the maximum allowed limit. Only models $\mathrm{C} 1$ and $\mathrm{X} 6$, therefore, presented a permanent linear deformation of less than $1 \mathrm{~mm}$ and were approved, presenting satisfactory performance.

No multi-support model was approved according to the evaluation method proposed, as can be seen in Table 22. Of all the types, this was the one that had the most variability with respect to the resisted load. This can be explained by the diversity of positions allowed for its application. This type of spacer can be positioned perpendicularly, in parallel, or diagonally to the bar.

In general, of the 28 spacer models evaluated in this requirement, 4 (B2, X9, C1 and X6) showed satisfactory performance and 24 had an unsatisfactory performance according to the established evaluation method.

\subsection{Application}

\section{Table 15 - Results of the stability requirement evaluation of the circular-type spacers of the manufacturers A, B and C}

\begin{tabular}{|c|c|c|c|c|c|c|c|}
\hline \multirow{3}{*}{$\begin{array}{l}\overline{\mathbf{0}} \\
\Phi \\
\Phi \\
\Phi\end{array}$} & Manufacturer & A & \multicolumn{3}{|c|}{ B } & \multicolumn{2}{|c|}{ C } \\
\hline & \multirow[b]{2}{*}{ Model } & A3 & B1 & B3 & B4 & $\mathrm{Cl}$ & $\mathrm{C}_{2}$ \\
\hline & & & & & & & \\
\hline & Type & $\begin{array}{l}\text { Circular } \\
\text { spacer }\end{array}$ & $\begin{array}{l}\text { Circular } \\
\text { spacer }\end{array}$ & $\begin{array}{l}\text { Circular } \\
\text { spacer }\end{array}$ & $\begin{array}{l}\text { Circular } \\
\text { spacer }\end{array}$ & $\begin{array}{l}\text { Circular } \\
\text { spacer }\end{array}$ & $\begin{array}{l}\text { Circular } \\
\text { spacer }\end{array}$ \\
\hline & Specified covering & 25 & 15 & 35 & 25 & 20 & 25 \\
\hline 斌 & Does it have stability? & Yes & Yes & No & No & Yes & No \\
\hline ๘ & Quantity of failed units & $0 / 15$ & $0 / 15$ & $15 / 15$ & $14 / 15$ & $0 / 15$ & $15 / 15$ \\
\hline
\end{tabular}


Table 16 - Results of the stability requirement evaluation of the circular-type spacers of the manufacturers $D, E$ and unknown manufacturers

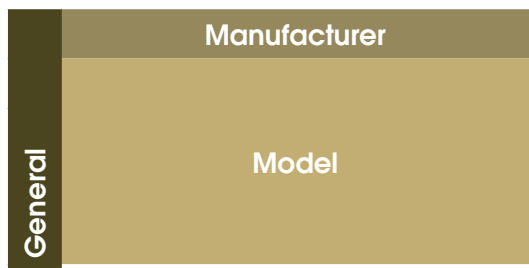

Type

Specified covering

Does it have stability?

Quantity of failed units

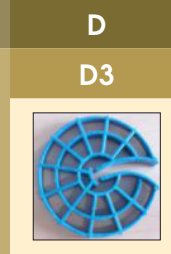

Circular spacer

40

No

$15 / 15$

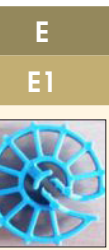

Circular spacer

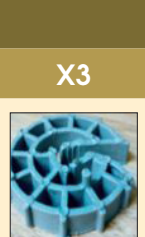

Circular spacer

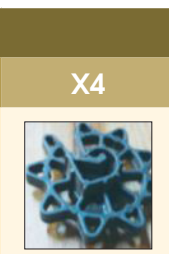

Circular spacer

20

Yes

$0 / 14$

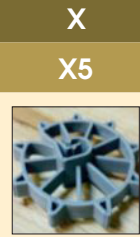

Circular spacer

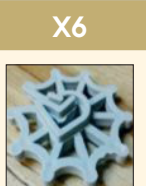

Circular spacer

20 $\mathrm{X} 7$

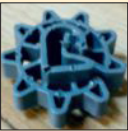

Circular spacer

15

Yes

$0 / 15$

Table 17 - Results of the stability requirement evaluation of the multi-support-type spacers of the manufacturers $C, D, E$ and unknown manufacturers

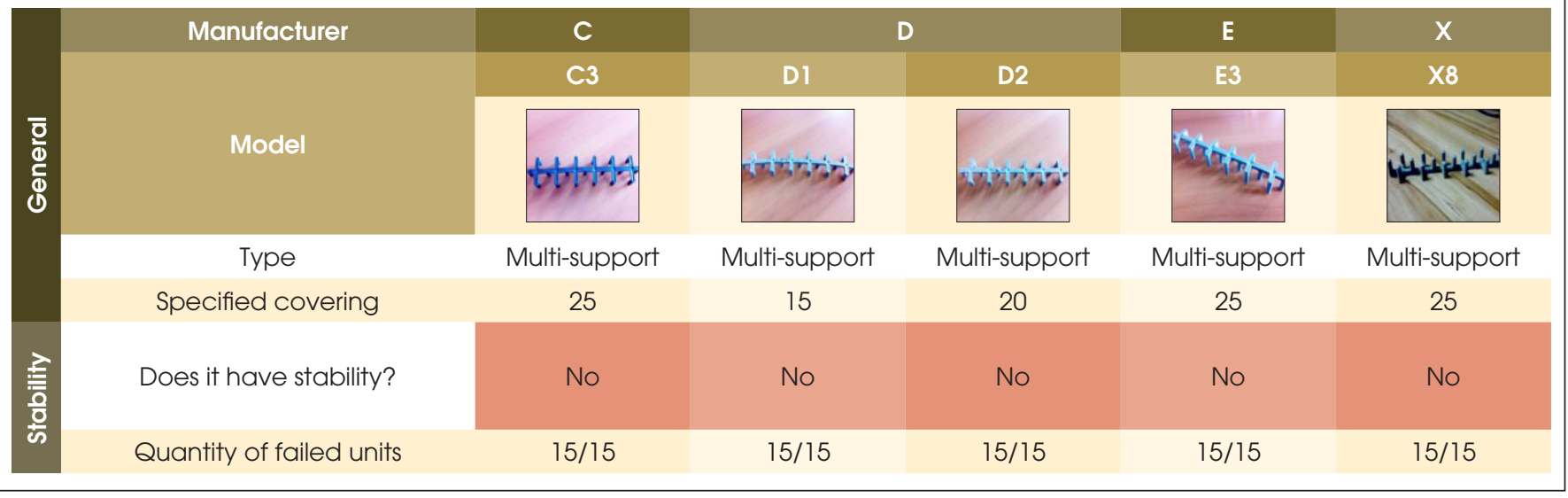

\begin{tabular}{|c|c|c|c|c|c|c|}
\hline \multicolumn{7}{|c|}{$\begin{array}{l}\text { Table } 18 \text { - Results of the load capacity requirement evaluation } \\
\text { of the chair-type spacers of the manufacturers A, B and C }\end{array}$} \\
\hline \multirow{5}{*}{$\begin{array}{l}\overline{\mathbf{0}} \\
\bar{\phi} \\
\bar{\Phi} \\
\mathcal{0}\end{array}$} & Manufacturer & \multicolumn{2}{|c|}{ A } & \multicolumn{2}{|c|}{ B } & c \\
\hline & \multirow[b]{2}{*}{ Model } & $\mathrm{Al}$ & A2 & B2 & B5 & $\mathrm{C} 4$ \\
\hline & & & & & & \\
\hline & Type & Chair & Chair & Chair & Chair & Chair \\
\hline & Specified covering & 15 & 15 & 20 & 25 & 20 \\
\hline \multirow{4}{*}{ 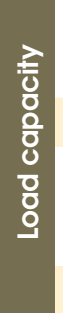 } & Does it have load capacity? & No & No & Yes & No & No \\
\hline & Quantity of failed units & $14 / 14$ & $15 / 15$ & $1 / 14$ & $15 / 15$ & $15 / 15$ \\
\hline & $\begin{array}{c}\rightarrow \text { If yes, was the permanent } \\
\text { linear deformation } \\
\text { less than } 1 \mathrm{~mm} \text { ? }\end{array}$ & N/A & N/A & Yes & N/A & N/A \\
\hline & Quantity of failed units & $14 / 14$ & $15 / 15$ & $1 / 14$ & $15 / 15$ & $15 / 15$ \\
\hline
\end{tabular}


Unlike the spacer models of the identified manufacturers, the models that were from unknown manufacturers were evaluated according to an alternative method because they didn't contain information regarding the largest recommended diameter for their application. This method consisted of trial and error, with the spacer being progressively applied from the smallest to the largest diameter until it could no longer be fitted with the maximum force required.
The results of the evaluation for the chair-type models are displayed in Table 23 and Table 24, which show that only models B2 and C4 were rejected, having an unsatisfactory performance.

For the circular spacers, models A3, B3, C1 and C2 were considered unsatisfactory because they failed the performance evaluation. All other models were approved in this requirement, as can be seen in Table 25 and Table 26.

All evaluated multi-support spacer models were approved according to the proposed evaluation method, according to Table 27 ,

\begin{tabular}{|c|c|c|c|c|c|c|}
\hline \multicolumn{7}{|c|}{$\begin{array}{l}\text { Table } 19 \text { - Results of the load capacity requirement evaluation of the } \\
\text { chair-type spacers of the manufacturer E and of unknown manufacturers }\end{array}$} \\
\hline \multirow{3}{*}{$\begin{array}{l}\overline{0} \\
\bar{\phi} \\
\bar{\phi} \\
\text { ర }\end{array}$} & Manufacturer & $\mathbf{E}$ & & & & \\
\hline & \multirow[b]{2}{*}{ Model } & E2 & $\mathbf{X} 1$ & $\mathrm{X} 2$ & $x_{9}$ & $\times 10$ \\
\hline & & & 1 & & & \\
\hline \multirow{6}{*}{$\begin{array}{l}\text { 정 } \\
8 \\
\frac{0}{8} \\
0 \\
8 \\
8 \\
0\end{array}$} & Type & Chair & Chair & Chair & Chair & Chair \\
\hline & Specified covering & $15 \mid 20$ & $25 \mid 30$ & 20 & 20 & 20 \\
\hline & Does it have load capacity? & No & No & No & Yes & No \\
\hline & Quantity of failed units: & $15 / 15$ & $15 / 15$ & $15 / 15$ & $0 / 11$ & $15 / 15$ \\
\hline & $\begin{array}{l}\rightarrow \text { If yes, was the permanent } \\
\text { linear deformation } \\
\text { less than } 1 \mathrm{~mm} \text { ? }\end{array}$ & N/A & N/A & N/A & Yes & N/A \\
\hline & Quantity of failed units & $15 / 15$ & $15 / 15$ & $15 / 15$ & $0 / 11$ & $15 / 15$ \\
\hline
\end{tabular}

\begin{tabular}{|c|c|c|c|c|c|c|c|}
\hline \multicolumn{8}{|c|}{$\begin{array}{l}\text { Table } 20 \text { - Results of the load capacity requirement evaluation } \\
\text { of the circular-type spacers of the manufacturers A, B and C }\end{array}$} \\
\hline \multirow{5}{*}{$\begin{array}{l}\overline{0} \\
\bar{\Phi} \\
\bar{\Phi} \\
\mathcal{L}\end{array}$} & Manufacturer & A & & B & & & \\
\hline & \multirow[b]{2}{*}{ Model } & A3 & B1 & B3 & B4 & $\mathrm{Cl}$ & $\mathrm{C} 2$ \\
\hline & & & & & & & \\
\hline & Type & $\begin{array}{l}\text { Circular } \\
\text { spacer }\end{array}$ & $\begin{array}{l}\text { Circular } \\
\text { spacer }\end{array}$ & $\begin{array}{l}\text { Circular } \\
\text { spacer }\end{array}$ & $\begin{array}{l}\text { Circular } \\
\text { spacer }\end{array}$ & $\begin{array}{l}\text { Circular } \\
\text { spacer }\end{array}$ & $\begin{array}{l}\text { Circular } \\
\text { spacer }\end{array}$ \\
\hline & Specified covering & 25 & 15 & 35 & 25 & 20 & 25 \\
\hline \multirow{4}{*}{$\begin{array}{l}\text { 응 } \\
\text { 응 } \\
\text { 응 } \\
\text { 응 }\end{array}$} & Does it have load capacity? & Yes & No & Yes & No & Yes & Yes \\
\hline & Quantity of failed units & $1 / 15$ & $2 / 15$ & $0 / 15$ & $2 / 15$ & $1 / 14$ & $0 / 15$ \\
\hline & $\begin{array}{c}\rightarrow \text { If yes, was the permanent } \\
\text { linear deformation } \\
\text { less than } 1 \mathrm{~mm} \text { ? }\end{array}$ & No & N/A & No & N/A & Yes & No \\
\hline & Quantity of failed units & $13 / 15$ & $15 / 15$ & $3 / 15$ & $15 / 15$ & $1 / 14$ & $4 / 15$ \\
\hline
\end{tabular}


showing no resistance to the application to the steel bar. In short, only 6 models failed the evaluation for this requirement, while 22 were approved with a satisfactory performance.

\section{Conclusions}

No spacer model evaluated proved to be satisfactory for all requirements and criteria proposed. Considering the requirements and performance criteria used as appropriate to evaluate the performance of the spacers, the spacers could be considered as one of probably factors for not achieving the project cover on current constructions.

It is clear, however, that all and any requirement and criteria established can be satisfied, since at least one spacer model was approved in each evaluation, except for the identification requirement, for which one can state that there are models of manufacturers that didn't participate in this assessment, but that do satisfy this requirement even if none of the evaluated models passed this criterion. Crossing the characteristics of the approved models in each requirement, therefore, it is possible to obtain a spacer with a suitable performance for its function.

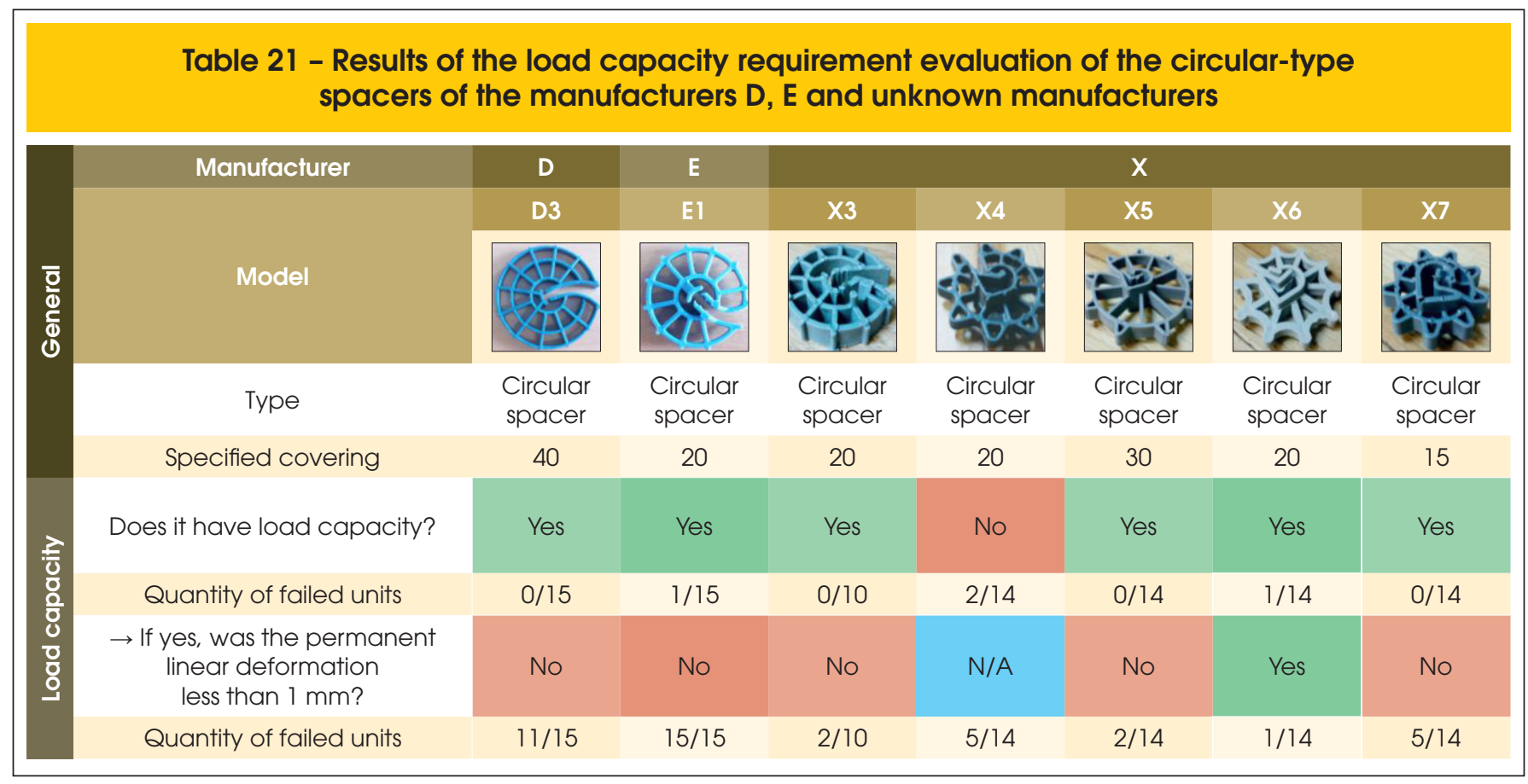

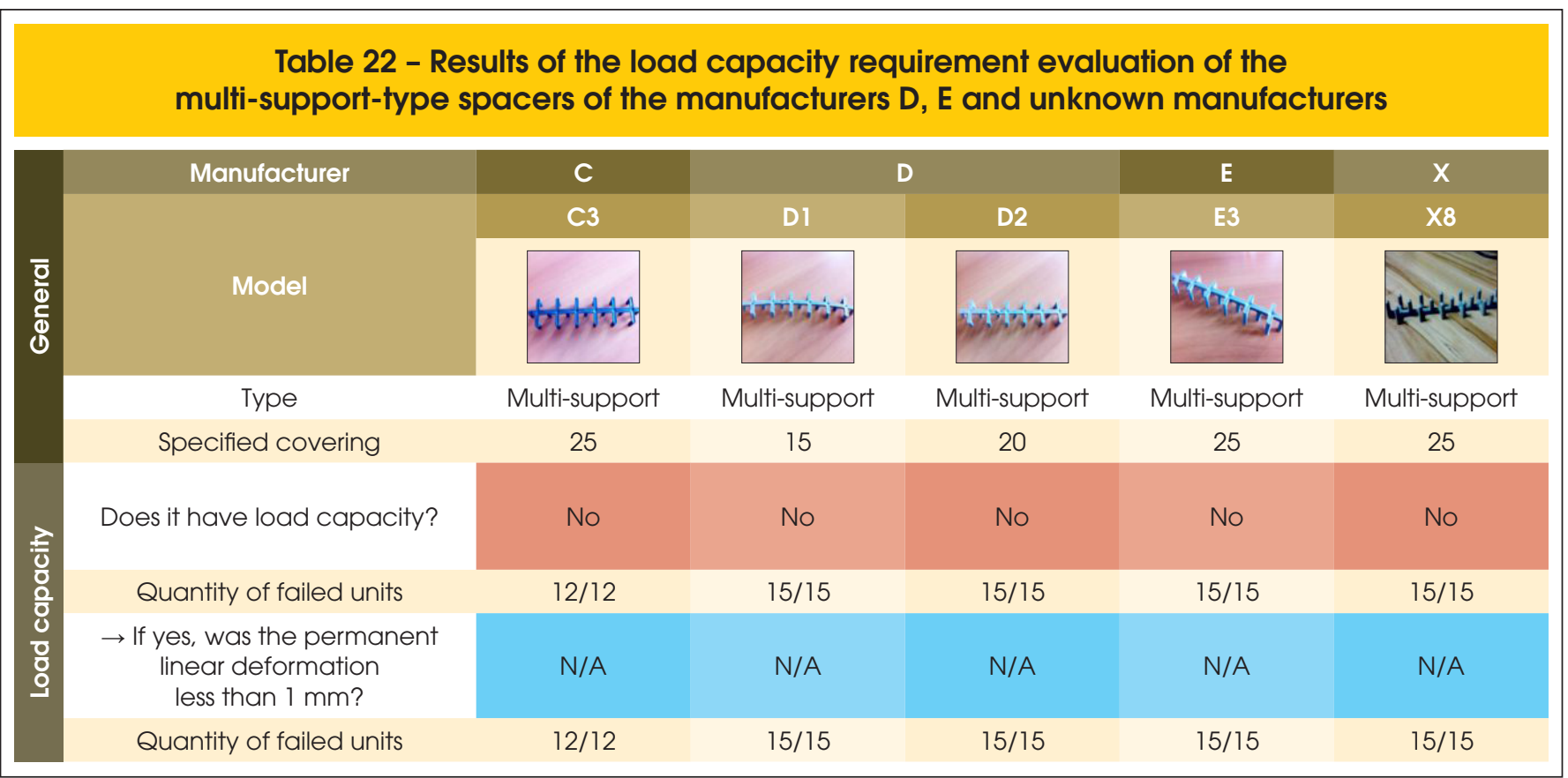




\section{Table 23 - Results of the application requirement evaluation of the chair-type spacers of the manufacturers A, B and C}

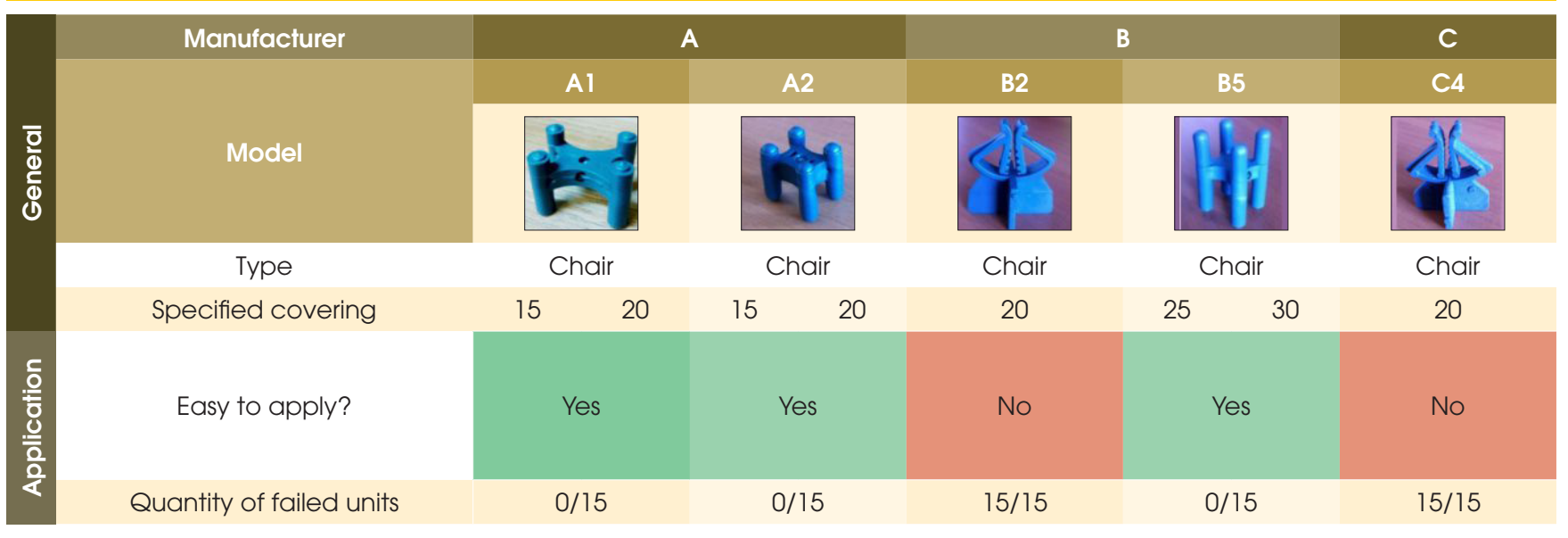

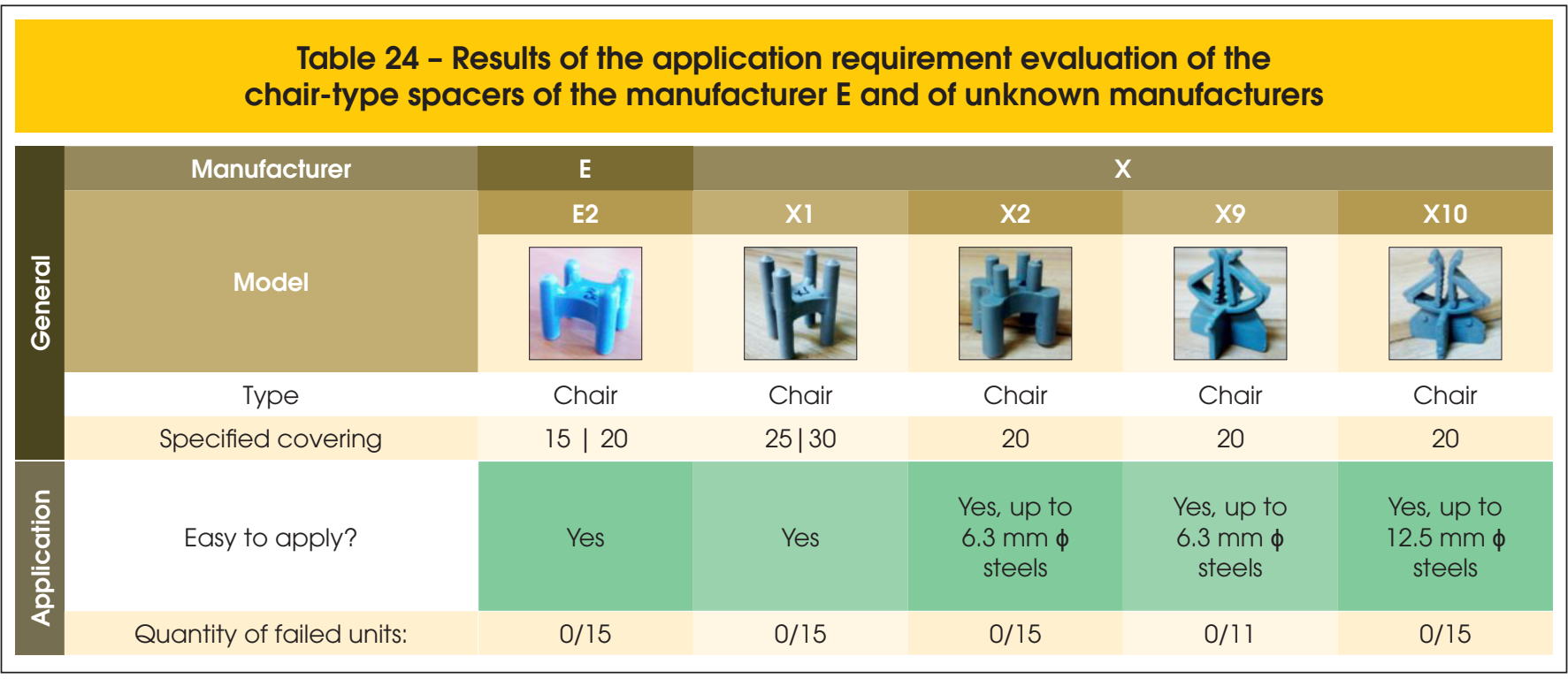

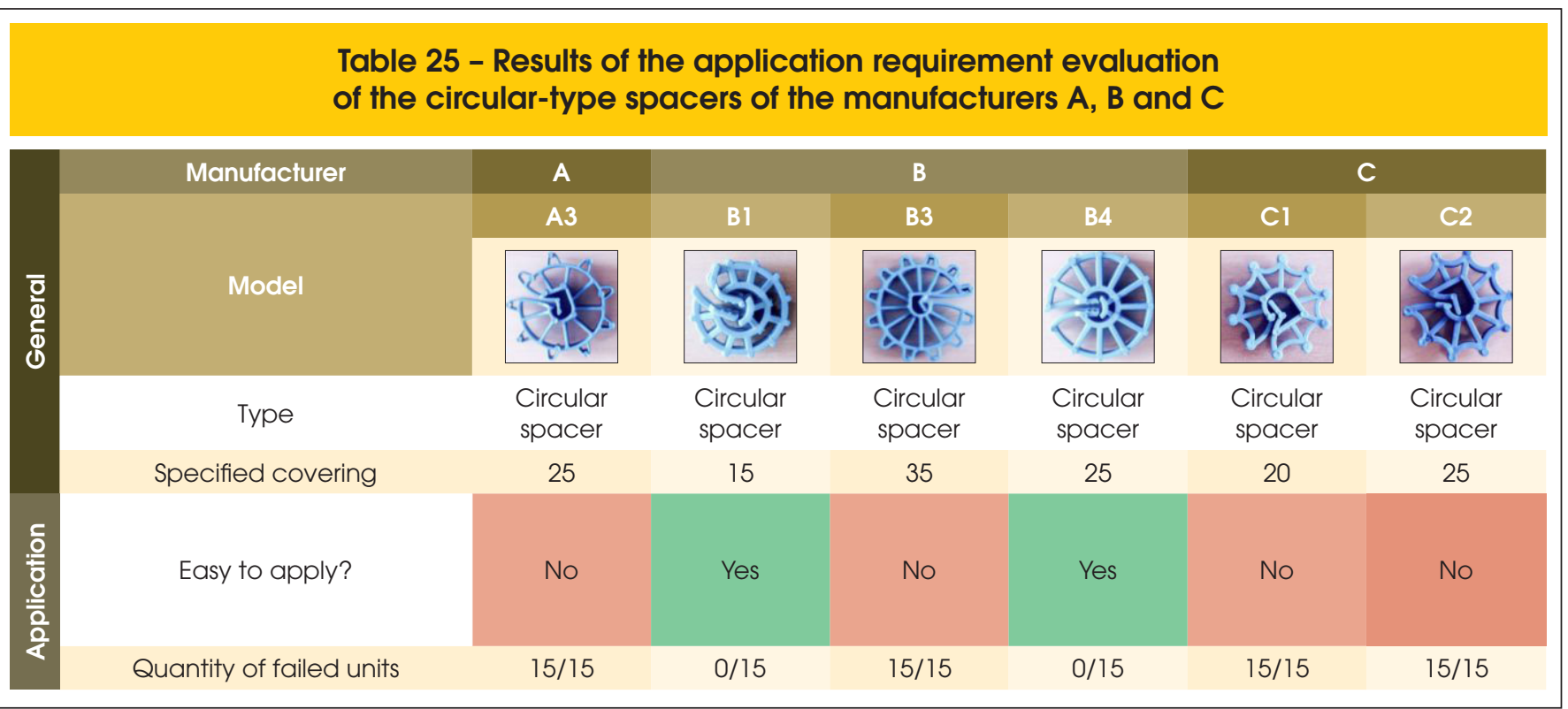


Considering the variety and diversity of spacers on offer, in addition to the different behavior of each one, the need for a regulatory standard for this product to outline the quality of spacers available on the market is revealed. For this would promote an improvement of the material, in addition to eliminating unsatisfactory products.

\section{Acknowledgments}

The authors would like to thank CAPES for supporting the research, the UFRGS and NORIE, in particular, for providing advisory services and providing the equipment, in addition to all those who helped in the development of this research.

\section{References}

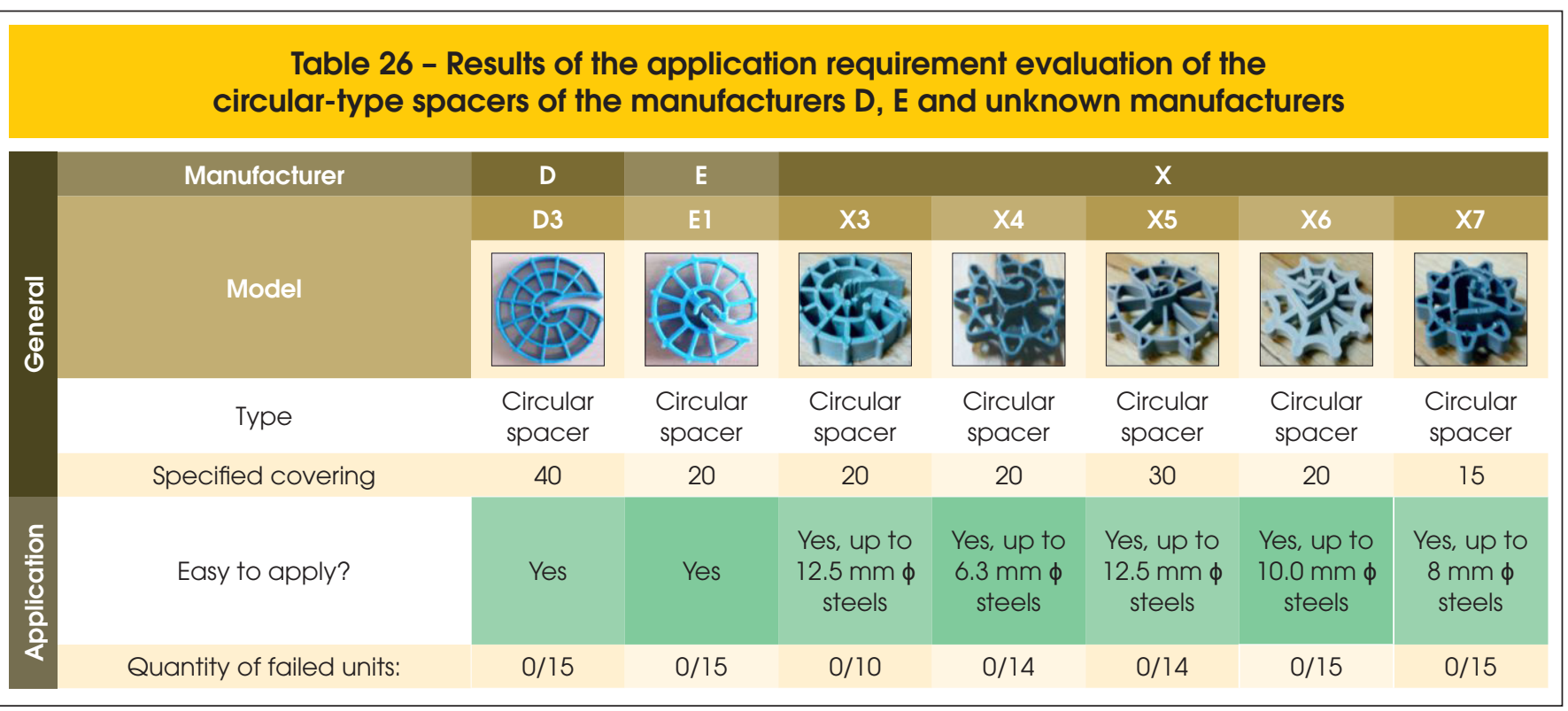

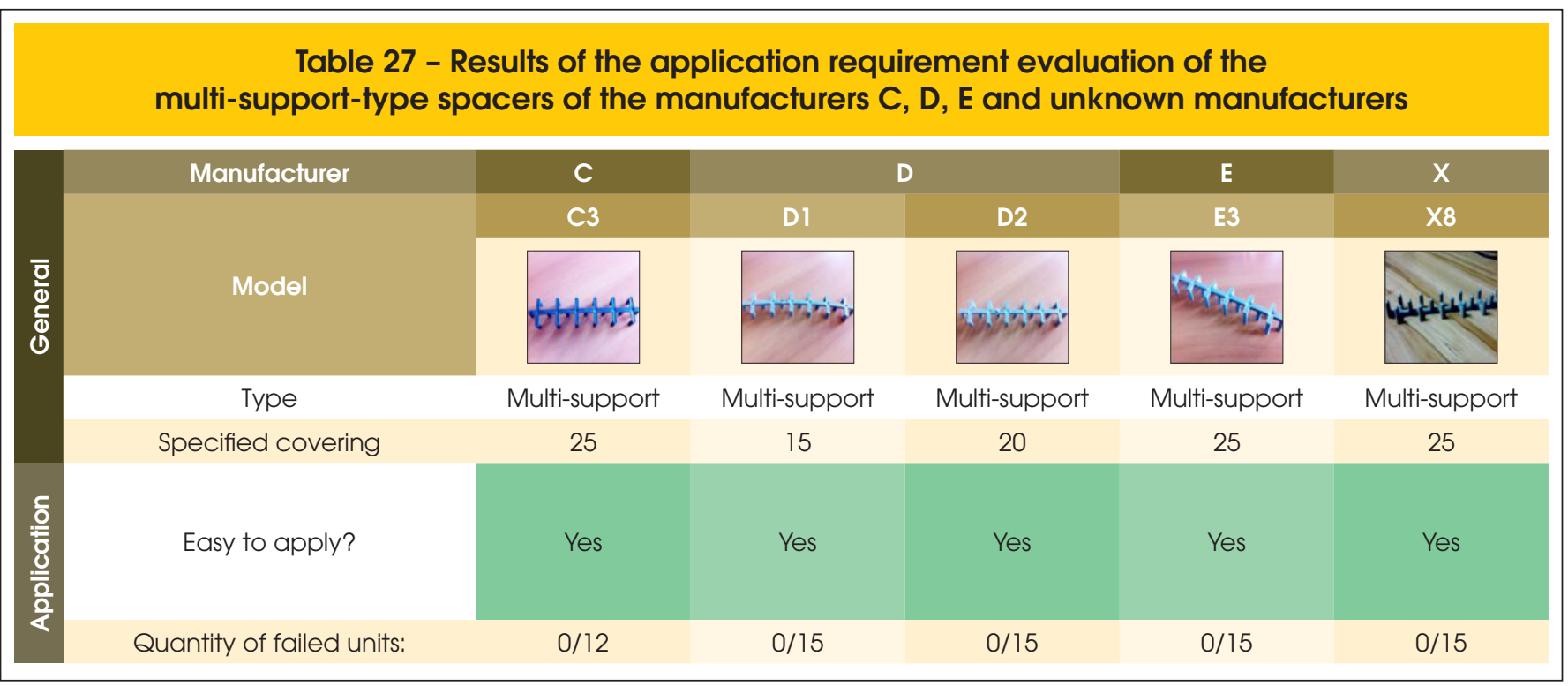
Beijing, 2007.

[2] ROSTAM, S. Service life design of concrete structures - A CCES01. In: Material and Structure. Ed. 41, page 717-731. challenge to designers as well as to owners. In: Asian Journal of Civil Engineering (Building and Housing). Vol 6, No 5. 2005.

[3] MARSH, B. Specification and achievement of cover to reinforcement. In: Advanced Concrete Technology Set. Volume 1, Pages 1 - 9, 2003.

[4] CLARK, L. A.; SHAMMAS-TOMA, M. G. K.; SEYMOUR, D. E.; PALLETT, P. F.; MARSH, B. K. How can we get the cover we need? In: The Structure Engineer. Journal of the Institution of Structural Engineers. Volume 75, № 17. UK, 2007. [5] SHAW, C. B. Durability of Reinforcement Concrete. 2007.

[1] LI, K.; CHEN, Z.; LIAN, H. Concepts and requirements of durability design for concrete structures: an extensive review of 
Disponível em: http://www.localsurveyorsdirect.co.uk/sites/ default/files/attachments/reinforced\%20concrete.pdf. Acesso em: maio 2014.

[6] MERRETZ, W. Achieving concrete cover in construction. In: Concrete in Australia. Technical Feature: Concrete cover. Vol 36, №1. Austrália, 2010.

[7] MARAN, A. P.; Menna Barreto, M. F. F.; ROHDEN, A. B.; DAL MOLIN, D. C. C.; MASUERO, J. R. Análise da espessura do cobrimento de armadura em lajes com diferentes distanciamentos entre espaçadores e pontos de amarração. In: Revista IBRACON de Estruturas e Materiais, 2015.

[8] MENNA BARRETO, M. F. F. Avaliação de desempenho de espaçadores plásticos: proposição e avanços de métodos de avaliação. Dissertação (Mestrado). Universidade Federal do Rio Grande do Sul. Programa de Pós-Graduação em Engenharia Civil, Porto Alegre, 2014.

[9] VAQUERO, J. Separadores para hormigón estructural. Zuncho n13. Septiembre, 2007.

[10] ASSOCIAÇÃO BRASILEIRA DE NORMAS TÉCNICAS. NBR 14931: Execução de estruturas de concreto - procedimento. Rio de Janeiro, 2004.

[11] BRITISH STANDARDS INSTITUTION (BSI). BS 7973: Spacers and chairs for steel reinforcement and their specification - Part 1: Product performance requirements. UK, 2001.

[12] COMITÉ EURO-INTERNATIONAL DU BÉTON (CEB). Bulletin d'Information No. 201 - Spacers, chairs and tying of steel reinforcement. Lausanne: Comité Euro-International du Béton, 1990.

[13] GIRIBOLOA, M. Espaçadores para armadura. In: Revista Equipe de Obra, Editora PINI, edição 62, São Paulo: agosto, 2013. .

[14] TINOCO, H. F. F.; FIGUEIREDO, E. J. P. Avaliação do desempenho de sistemas de reparo e recuperação para estruturas de concreto com corrosão das armaduras. In: WORKSHOP SOBRE DURABILIDADE DAS CONSTRUÇÕES, 2., 2001, São José dos Campos. Anais... São José dos Campos: ITA, 2002.

[15] SPEKKINK, D. Performance based design: Bringing Vitruvius up to date. Performance Based Building Thematic Network. Domain 3 Report. Holanda: novembro, 2005.

[16] ASSOCIAÇÃO BRASILEIRA DE NORMAS TÉCNICAS. NBR 15575: Edificações Habitacionais: Desempenho - Parte 1: Requisitos Gerais. Rio de Janeiro, 2013.

[17] ASSOCIAÇÃO BRASILEIRA DE NORMAS TÉCNICAS. NBR 6118: Projeto de estruturas de concreto - Procedimento. Rio de Janeiro, 2014. 